\title{
Effective source rock selection and oil-source correlation in the Western Slope of the northern Songliao Basin, China
}

\author{
$\mathrm{He} \mathrm{Bi}^{1} \cdot$ Peng $\mathrm{Li}^{2} \cdot$ Yun Jiang ${ }^{1} \cdot$ Jing-Jing Fan ${ }^{1} \cdot$ Xiao-Yue Chen ${ }^{3}$
}

Received: 5 May 2020 / Accepted: 13 October 2020 / Published online: 8 March 2021

(c) The Author(s) 2021

\begin{abstract}
This study considers the Upper Cretaceous Qingshankou Formation, Yaojia Formation, and the first member of the Nenjiang Formation in the Western Slope of the northern Songliao Basin. Dark mudstone with high abundances of organic matter of Gulong and Qijia sags are considered to be significant source rocks in the study area. To evaluate their development characteristics, differences and effectiveness, geochemical parameters are analyzed. One-dimensional basin modeling and hydrocarbon evolution are also applied to discuss the effectiveness of source rocks. Through the biomarker characteristics, the source-source, oil-oil, and oil-source correlations are assessed and the sources of crude oils in different rock units are determined. Based on the results, Gulong and Qijia source rocks have different organic matter primarily detrived from mixed sources and plankton, respectively. Gulong source rock has higher thermal evolution degree than Qijia source rock. The biomarker parameters of the source rocks are compared with 31 crude oil samples. The studied crude oils can be divided into two groups. The oil-source correlations show that group I oils from Qing II-III, Yao I, and Yao II-III members were probably derived from Gulong source rock and that only group II oils from Nen I member were derived from Qijia source rock.
\end{abstract}

Keywords Songliao basin $\cdot$ Western slope $\cdot$ Source rock distinction $\cdot$ Crude oils $\cdot$ Biomarker $\cdot$ Oil-source correlation

\section{Introduction}

As an important part of oil and gas geology research, the detailed study of source rock characteristics and oil-source correlation can provide direct guidance during oil and gas exploration and can assist with the further deployment of oil and gas exploration. Oil-source correlation is based on the concept that some components of oil and gas discharged from the source rocks are relatively similar to those of the oil and gas remaining in the source rocks (Peters and Moldowan 1993; Peters et al. 2005; Bennett et al. 2006). The source of oil and gas directly affects oil and gas accumulation and

Edited by Jie Hao and Chun-Yan Tang

$\mathrm{He} \mathrm{Bi}$

gloria_hebi@126.com

1 Research Institute of Petroleum Exploration and Development, PetroChina, Beijing 100083, China

2 Petroleum Exploration and Production Research Institute, SINOPEC, Beijing 100083, China

3 China National Oil and Gas Exploration and Development Co. Ltd., Beijing 100034, China reservoir distribution (Dow 1974; Schoell 1980; Tissot 1984; Magoon and Dow 1991). The detailed study of oil-source correlation can provide favorable information on the genesis and migration direction of oil and gas, thus leading to the discovery of new exploration fields (Tissot 1984). As one of the most important preliminary factors in oil-source correlation, the selection of source rocks and determining oil-oil correlations are indispensable steps (Dong et al. 2015; Mashhadi and Rabbani 2015; Brito et al. 2017).

The study of oil and gas sources can be performed with many available comparative indicators, including terpenes, steranes, $n$-alkanes, cycloalkanes, aromatic hydrocarbons and typical abiogenic heteratomic compounds, such as thiophene and carbazole derivatives (Dong et al. 2015; Mashhadi and Rabbani 2015; Brito et al. 2017; Zhang et al. 2019). When an oil-source correlation is made, multifactor comparison is often adopted. Intuitively, the relationship between the source rock and crude oil can be judged by observing the degree of similarity in the biomarker "fingerprint" and by comparing the parameter ratios of light hydrocarbon compounds and biomarkers.

This study considers the Western Slope of the northern Songliao Basin, China, as an example to investigate the 
source rock characteristics and to differentiate the sources of the oils in different formations based on the analysis of oil-source correlation. To date, most research has focused on the Qijia-Gulong sag as a single unit to explore the source rock characteristics in this region, and little attention has been focused on the differences and effectiveness of the source rocks between Gulong and Qijia sags (Zou et al. 2004; Feng et al. 2005; Zhou et al. 2006; Meng et al. 2014). Thus, the oils of different formations in the Western Slope and their sources remain little attention to distinguish. Therefore, this study investigates the source rock characteristics between the Gulong and Qijia sags, determines the differences and effectiveness of the hydrocarbon supply, and discusses the source-source, oil-oil and oil-source correlations. This study is essential for understanding the sources of the discovered oils in different formations and for helping to explore the direction of oil and gas migration and significant exploration potential in the study area.

\section{Geological setting}

The Songliao Basin occupies an area of $2.6 \times 10^{5} \mathrm{~km}^{2}$, and six first-order tectonic zones are developed in the basin, namely the Western Slope, Northern pitching, Northeast uplift, Central depression, Southwest uplift, and Southeast uplift. To better investigate the sources of crude oils in the Western Slope tectonic zone, the eastern edge of the study area extends to the axis of Central depression, which contains the main source rocks. The study area covers an area of $2.4 \times 10^{4} \mathrm{~km}^{2}$ and is divided into five tectonic zones: the Western overlap zone, Taikang uplift belt, Longhupao-Da'an terrace, Qijia sag and Gulong sag (Fig. 1). The oil resources in the study area are abundant and are distributed in multiple sets of strata (Meng et al. 2014).

Several sets of strata are drilled in the study area (Fig. 2). In this study, the Upper Cretaceous Qingshankou Formation (Qing I and Qing II-III members), Yaojia Formation (Yao I and Yao II-III members), and the first member of the Nenjiang Formation (Nen I member) are considered target strata based on the main distribution of the oil system in the study area. Source rocks are mainly present in the Qing I member and the Nen I member of Gulong and Qijia sags, and oil reservoirs are mainly present in the Qing II-III member, the Yaojia Formation and the Nen I member of Western Slope (Gao and Cai 1997; Fu et al. 2001; Kang et al. 2005; Zhou et al. 2006; Hou et al. 2009; Meng et al. 2014; Zhu et al. 2016; Bi et al. 2017).

\section{Samples and methods}

A detailed study was conducted based on the geochemical analyses of mudstone and oil-bearing sandstone samples. Total organic carbon (TOC), Rock-Eval pyrolysis, vitrinite reflectance, and $n$-alkanes data were obtained from the database of the Exploration and Development Research Institute of Daqing Oilfield, China. In addition, five mudstone cores (from Wells Y78, G572, G3 and D37, with depth of 1796-2322 m) were collected from the Gulong and Qijia
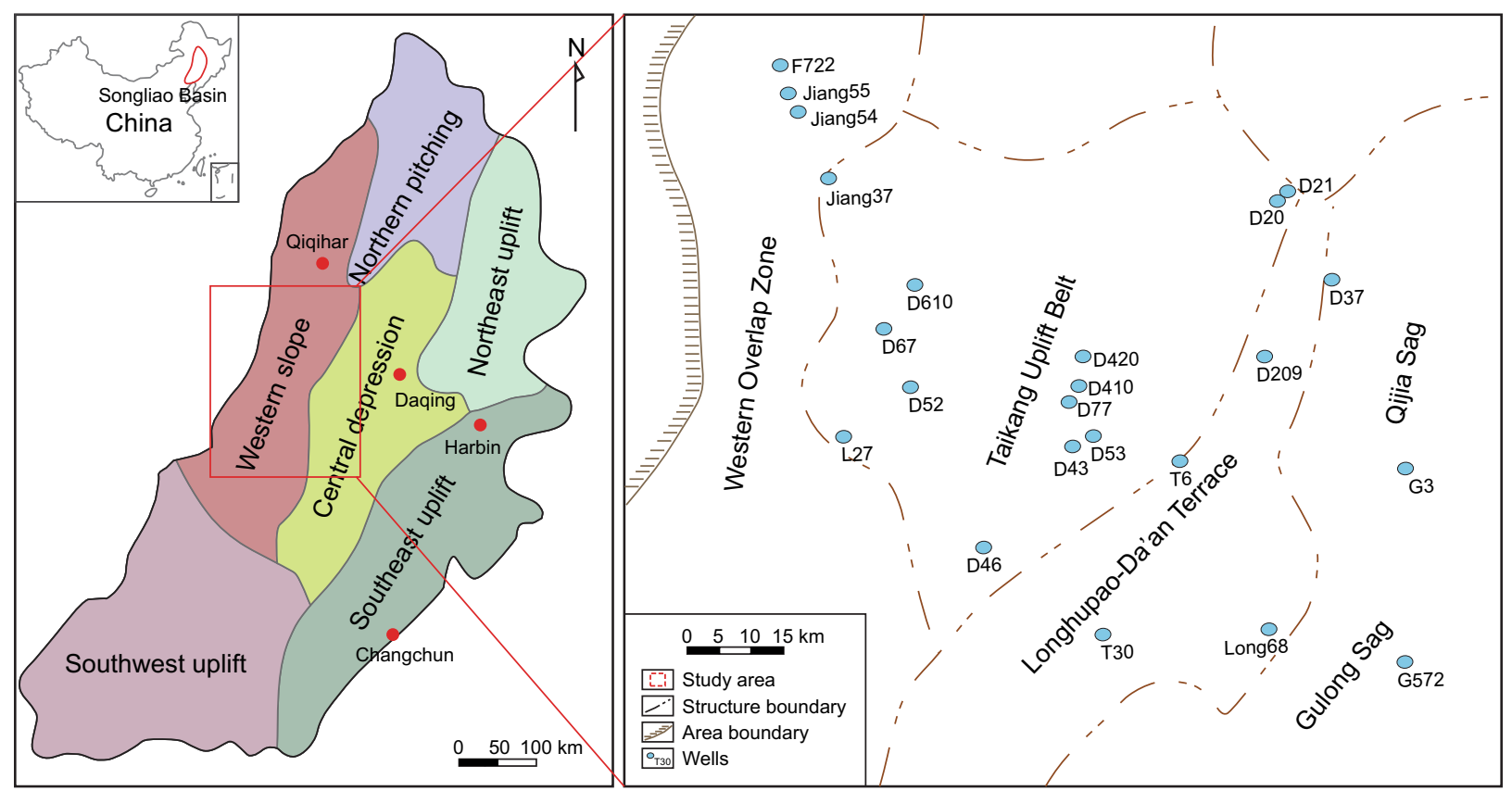

Fig. 1 Tectonic unit division, including the Western Slope of the Songliao Basin with location of well samples 


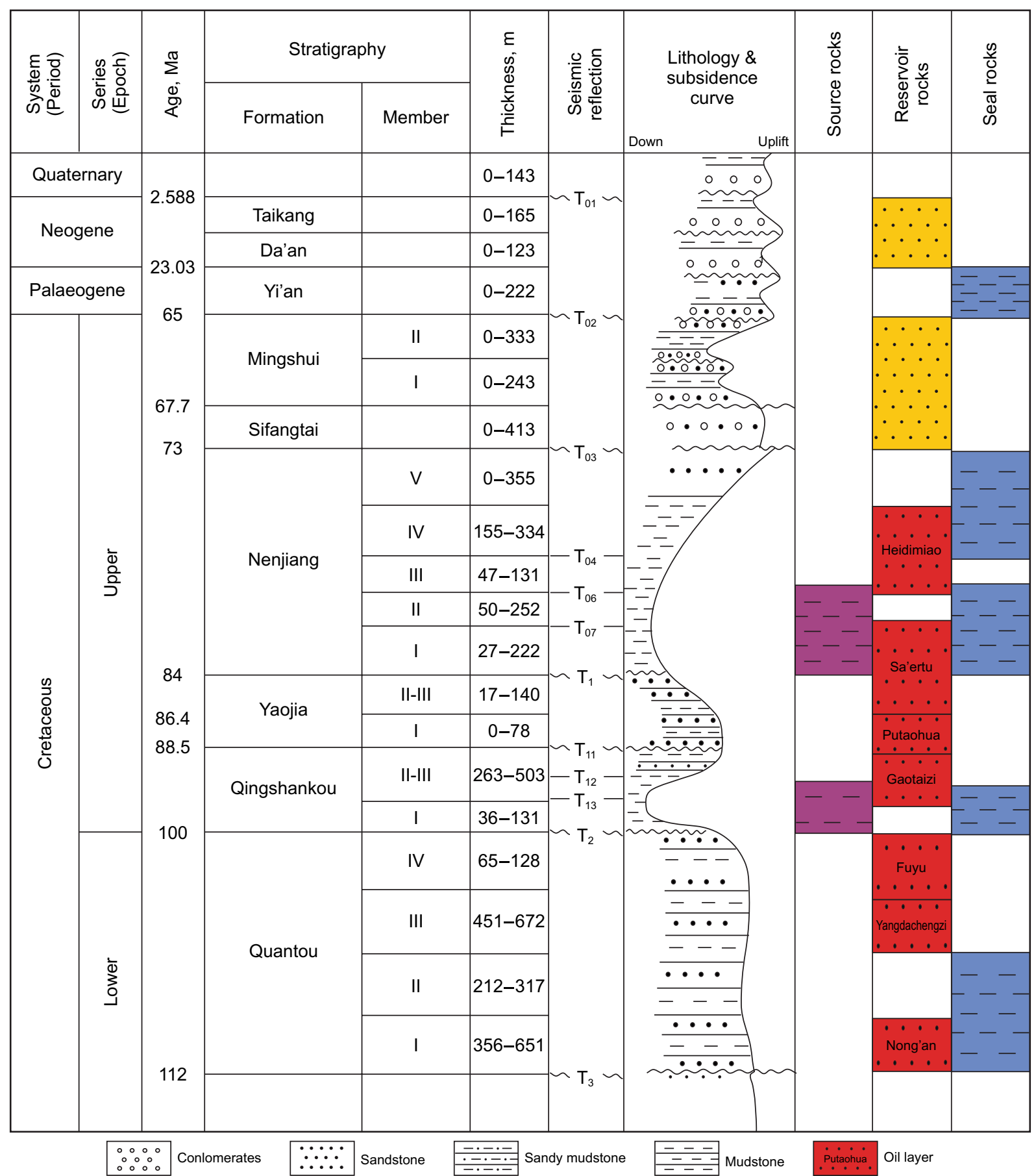

Fig. 2 Stratigraphic division and the major petroleum system elements of the study area in the Songliao Basin (after Bi et al. 2017)

sags, and 31 oil-bearing sandstone cores were collected from the Western Slope (Fig. 1). These core samples were subjected to bitumen extraction and gas chromatography-mass spectrometry (GC-MS) to define their molecular biomarker compositions. The analyses were carried out at Petroleum Geology Research and Laboratory Center, RIPED.

Asphaltenes were removed from oil-bearing sandstone samples by precipitation with $n$-hexane. Saturated and aromatic hydrocarbons were separated by sequential elution with $n$-hexane and a solution of $n$-hexane and dichloromethane $(2: 1 \mathrm{v}: \mathrm{v})$ on activated silica gel/alumina columns. The saturated fractions were analyzed using a Thermo-Trace GC Ultra-DSQ II GC-MS device. The GC uses an HP-5MS capillary column $(60 \mathrm{~m} \times 0.25 \mathrm{~mm} \times 0.25 \mathrm{~mm})$ with helium as the carrier gas $(1.0 \mathrm{~mL} / \mathrm{min})$. The temperature of the $\mathrm{GC}$ oven was set to $100{ }^{\circ} \mathrm{C}$ for $5 \mathrm{~min}$, increased to $220^{\circ} \mathrm{C}$ at 

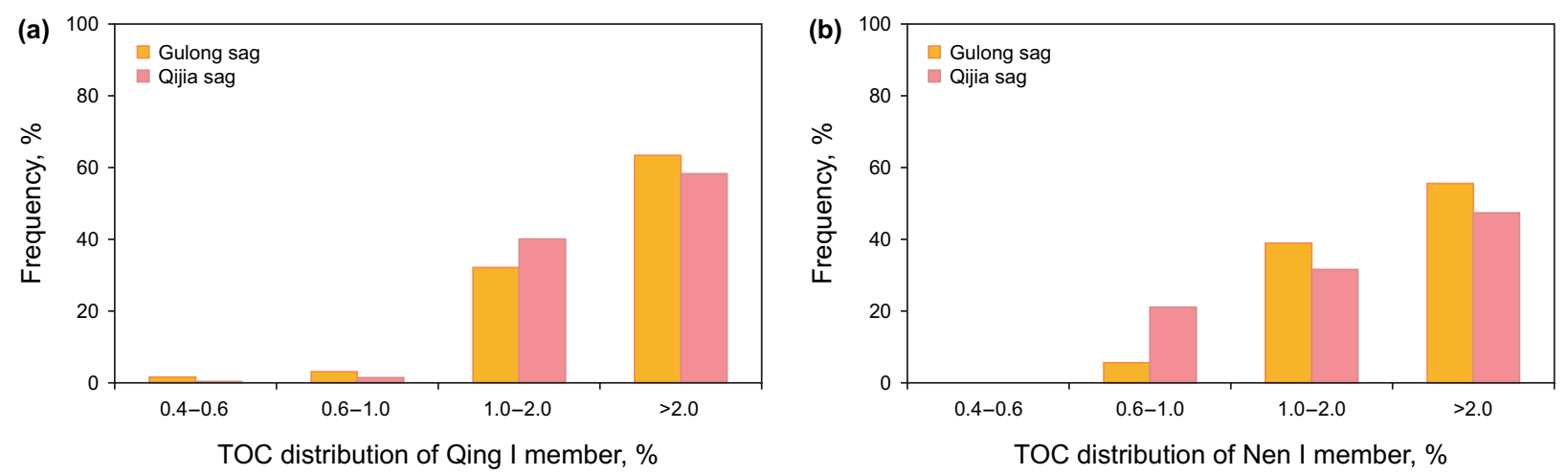

Fig. 3 Frequency distribution of the TOC values in the (a) Qing I and (b) Nen I source rocks in the Gulong and Qijia sags

$4{ }^{\circ} \mathrm{C} / \mathrm{min}$ and then to $320^{\circ} \mathrm{C}$ at $2{ }^{\circ} \mathrm{C} / \mathrm{min}$, and finally held for $20 \mathrm{~min}$. The mass spectrometer was operated in Electron Impact (EI) mode with an ionization energy of $70 \mathrm{eV}$ and an ion source temperature of $280{ }^{\circ} \mathrm{C}$. Based on selected ion monitoring, the mass-to-charge ratios of 177, 191, 217, 218 and 221 were determined. In this study, the fractions were analyzed using the following ion monitoring modes: $\mathrm{m} / \mathrm{z}$ 191 and $\mathrm{m} / \mathrm{z} 217$.

\section{Results and discussion}

\subsection{Source rock evaluation and generation potential}

The evaluation of the Upper Cretaceous source rocks in the Gulong and Qijia sags is discussed based on the TOC, $n$-alkane, Rock-Eval pyrolysis, vitrinite reflectance and molecular analysis data. This evaluation assisted in selecting the effective source rocks and defining the differences among the source rocks in different tectonic units and formations.

\subsubsection{Organic matter abundance}

The TOC values of the source rocks range from $0.55 \%$ to $8.31 \%$, with an average value of $2.41 \%$, indicating fair-toexcellent petroleum potential (Diasty et al. 2019). The TOC values of the source rock in the Qing I member range from $0.55 \%$ to $8.31 \%$, with an average value of $2.36 \%$. The TOC values of the source rock in the Nen I member range from $0.72 \%$ to $8.06 \%$, with an average value of $2.80 \%$. According to Fig. 3, the TOC distributions of the source rocks in different tectonic units and formations are analyzed. The Qing I source rock has the highest TOC content. 97.5\% of the Qing I samples have TOC $>1.0 \%$ and $59.6 \%$ of the samples have TOC $>2.0 \%$, indicating good-to-excellent potential (Fig. 3a). The unit with the second highest TOC values is the Nen I source rock, in which $89.1 \%$ of samples have
TOC $>1.0 \%$ and $52.7 \%$ of the samples have $\mathrm{TOC}>2.0 \%$ indicating good-to-excellent potential (Fig. 3b).

\subsubsection{Organic matter type}

Plots of Rock-Eval hydrogen index (HI) versus $T_{\max }$ (Fig. 4) for Qing I and Nen I samples in the Gulong and Qijia sags show the organic matter type of the source rocks. HI values of Qing I samples in Gulong sag range from 71 to $455 \mathrm{mg} / \mathrm{g}$ TOC and those in Qijia sag range from 222 to $823 \mathrm{mg} / \mathrm{g}$ TOC, demonstrating that the Qing I source rock in the Gulong sag is primarily Type II-III kerogen and that in Qijia sag is mainly Type I-II kerogen (Fig. 4a). HI values of Nen I samples in Gulong sag range from 227 to $762 \mathrm{mg} / \mathrm{g}$ TOC and those in Qijia sag range from 318 to $799 \mathrm{mg} / \mathrm{g}$ TOC, demonstrating that the Nen I source rocks in the Gulong and Qijia sags are mixed Type I-II kerogen (Fig. 4b).

\subsubsection{Depositional environment and provenance}

Isoprenoids are commonly used to determine the sedimentary environment. Pristane (Pr) and phytane (Ph) are the most abundant and ubiquitous isoprenes and are often used to determine whether the original depositional environment was oxidizing or reducing. Oxidation preferentially promotes the conversion of phytols into pristane, while reduction promotes the conversion of dihydrophytol to phytane (Brooks et al. 1969; Ten Haven et al. 1987; Rowland 1990; Rontani et al. 2013; Schouten et al. 2013). The Pr/Ph ratios of the source rocks in the sags are generally $0.8-1.8$, showing a suboxic condition (Fig. 5). In addition, relatively low $\mathrm{Pr} / n-\mathrm{C}_{17}$ and $\mathrm{Ph} / n-\mathrm{C}_{18}$ ratio values (Fig. 6) represent nonbiodegraded hydrocarbons generated from the source rocks, which were deposited in a suboxic condition.

Sterane, as a biogenic indicator in sediments, has been widely used to obtain information about the sedimentary environment and the source properties (Peters et al. 2005). Sterane compounds are mostly derived from algae, 

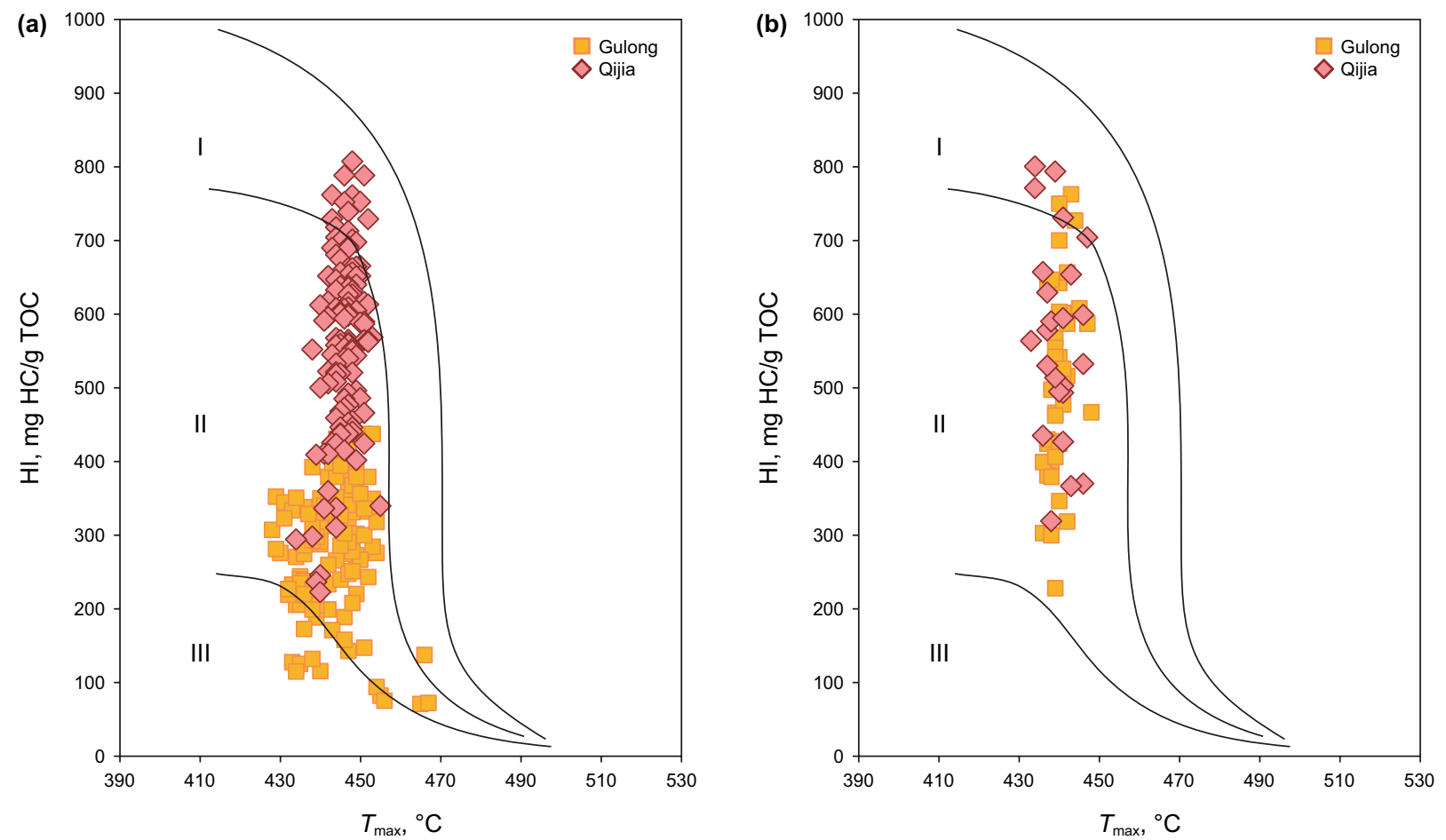

Fig. 4 Variation of Rock-Eval hydrogen index with $T_{\max }$ for samples from the (a) Qing I and (b) Nen I source rocks in the Gulong and Qijia sags, showing organic matter type

phytoplankton and higher plants. After deposition, the organic matter is converted from sterol to sterane by steroidal diene during heating (Peters et al. 2005). In general in source rocks and crude oils, the most common steranes include $\mathrm{C}_{27}-\mathrm{C}_{29}$ steranes. It is generally recognized that $\mathrm{C}_{27}$ and $\mathrm{C}_{28}$ regular steranes originate from the lower aquatic organisms and algae, and $\mathrm{C}_{29}$ steranes are typically from terrestrial higher plants ( $\mathrm{Li}$ et al. 2017). Therefore, a ternary diagram of $5 \alpha, 14 \alpha, 17 \alpha(20 \mathrm{R}) \mathrm{C}_{27}, \mathrm{C}_{28}$, and $\mathrm{C}_{29}$ steranes can be used to identify the organic matter source (Cai et al. 2009). The relative distribution of $\mathrm{C}_{27}, \mathrm{C}_{28}$, and $\mathrm{C}_{29}$ steranes were plotted on a sterane ternary diagram (Fig. 7). In comparison with samples from Gulong and Qijia sags, samples from Gulong sag are toward $\mathrm{C}_{29}$ sterane and those from Qijia sag are toward $\mathrm{C}_{27}$ sterane. These show that the organic matter in the Gulong sag is primarily derived from mixed sources, while that in the Qijia sag is primarily derived from plankton (Fig. 7).

\subsubsection{Thermal maturity}

Vitrinite reflectance $\left(R_{\mathrm{o}}\right)$, as a maturity parameter, is commonly used to evaluate the degree of evolution. The $R_{\mathrm{o}}$ values of the source rocks in the study area range from
$0.34 \%$ to $2.02 \%$, with an average of $0.80 \%$, which corresponds to the mature oil-generating stage. The $R_{\mathrm{o}}$ values of the Qing I member range from $0.44 \%$ to $2.02 \%$, with an average of $0.94 \%$. The $R_{\mathrm{o}}$ values of the Nen I member range from $0.34 \%$ to $1.18 \%$, with an average of $0.58 \%$. It can be clearly seen that the thermal maturity of the source rocks in the Qing I member is relatively high, while that in the Nen I member is low.

The planar $R_{\mathrm{o}}$ distribution maps of the study area show that the mature source rocks are widely distributed (Fig. 8). The rocks with a high thermal maturity of organic matter are distributed in the sags, where the $R_{\mathrm{o}}$ values are generally higher than $0.9 \%$. The source rocks with the highest maturity are located in the Gulong sag, and the highest $R_{\mathrm{o}}$ is greater than $2.0 \%$, followed by the source rocks in Qijia sag, with $R_{\mathrm{o}}$ values greater than $1.5 \%$. From the depression to the slope, the maturity gradually decreases. In the west of the Taikang uplift belt and the Western overlap zone, the $R_{\mathrm{o}}$ values are less than $0.7 \%$, and the organic matter is in the immature stage. In terms of planar distribution maps of each source rock, the mature source rocks of the Qing I member are widely distributed from the sags to the west of the Taikang uplift belt, while 
the mature source rocks of the Nen I member are present only in sags and the Longhupao-Da' an terrace (Fig. 8).

In addition, this study also compares the thermal evolution degree of the source rocks in the two sags based on the $\sum \mathrm{C}_{21}{ }^{-} / \sum \mathrm{C}_{22}{ }^{+} n$-alkane ratio. In the process of continuous thermal evolution of organic matter in source rocks, $\mathrm{n}$-alkanes with high molecular weights gradually decrease in abundance, while those with low molecular weights increase in abundance. These results indicate that the $\sum \mathrm{C}_{21}{ }^{-} / \sum \mathrm{C}_{22}{ }^{+}$ $n$-alkane ratio has increased. According to the statistics of the $\sum \mathrm{C}_{21}{ }^{-} / \sum \mathrm{C}_{22}{ }^{+}$ratios in each source rock, the ratios in the Gulong sag are obviously higher than those in the Qijia sag (Fig. 9). This indicates that the thermal evolution degree of the source rocks in the Gulong sag is higher than that in the Qijia sag.

\subsubsection{Main source rock}

The moderately to shallowly buried source rocks in the Songliao Basin generated and expelled hydrocarbons relatively late, within a narrow range. The source rocks began to expel hydrocarbons with $12 \%$ conversion rate when the $R_{\mathrm{o}}$ value reached $0.75 \%$, and the conversion rate reached $70 \%$ when the $R_{\mathrm{o}}$ value reached $0.90 \%$ (Li 2019). Therefore, based on the planar $R_{\mathrm{o}}$ distribution, the area with $R_{\mathrm{o}}$ values greater than $0.75 \%$ represents the area with effective source rocks in the study area, and these areas are mainly within the sags. Some source rocks in the slope area have reached the mature stage but failed to exhibit effective hydrocarbon expulsion. The effective source rocks in the Qing I member have the largest distribution range, reaching the eastern edge of the Taikang uplift. The distribution ranges of the effective source rocks in the Nen I members are smaller and are limited to the Longhupao-Da'an terrace, the Qijia sag and the Gulong sag.

The moderately to shallowly buried strata of the northern Songliao Basin experienced two periods of large-scale uplift and denudation during later periods corresponding to the deposition of the Nenjiang Formation and Mingshui Formation. These two periods of large-scale tectonic movement affected the hydrocarbon generation and expulsion of source rocks in the Gulong and Qijia sags (Zhou et al. 2006; Wen 2012). Two typical wells in the Gulong and Qijia sags (Wells G572 and G3, respectively) are selected to simulate the burial history and maturity evolution (pressure gradient is $1.03 \mathrm{MPa} / 100 \mathrm{~m}$ and thermal gradient is $4.36{ }^{\circ} \mathrm{C} / 100 \mathrm{~m}$ ) (Figs. 10 and 11). As shown in Fig. 10, the Qing I source rock in the Gulong sag reached the mature stage during the period of the first uplift, and the $R_{\mathrm{o}}$ value was greater than $0.75 \%$, indicating that hydrocarbon generation and expulsion could have initiated. In contrast, the Nen I source rocks did not reach the mature stage during the period of the first

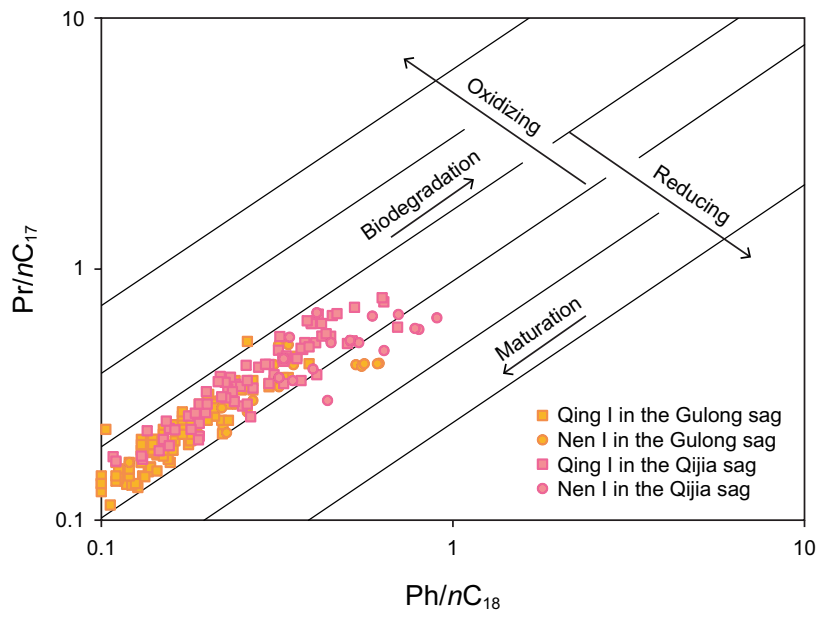

Fig. 6 Plot of $\mathrm{Pr} / n \mathrm{C}_{17}$ versus $\mathrm{Ph} / n \mathrm{C}_{18}$ showing maturation and depositional environment in the studied source samples

uplift and failed to generate and discharge hydrocarbon during that period. As shown in Fig. 11, the source rocks in the Qijia sag did not reach the hydrocarbon generation and
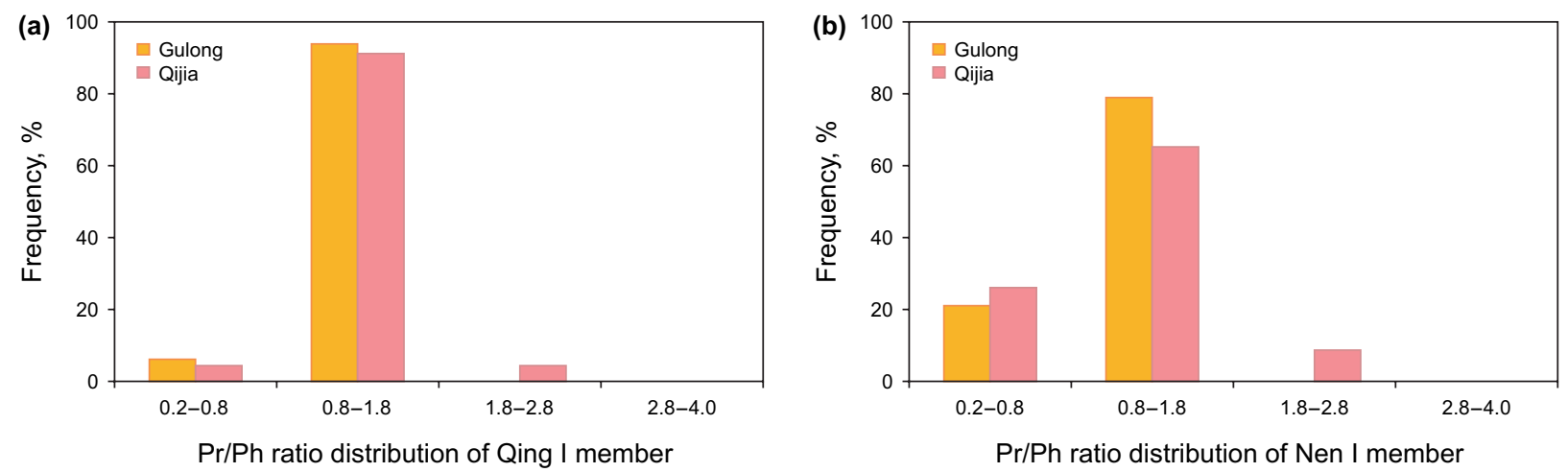

Fig. 5 Frequency distribution of $\mathrm{Pr} / \mathrm{Ph}$ ratios in the (a) Qing I and (b) Nen I source rocks in the Gulong and Qijia sags 


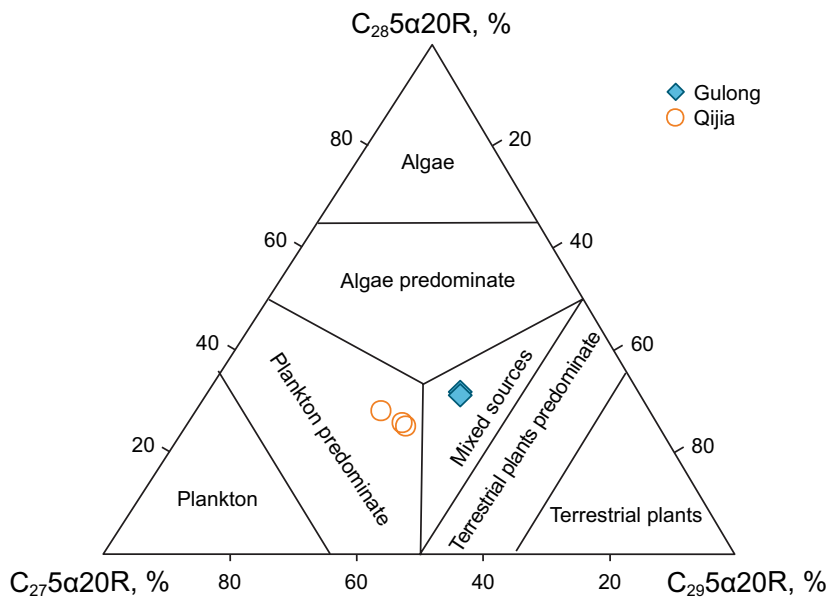

Fig. 7 Ternary diagram showing the relative abundance of $\mathrm{C}_{27}, \mathrm{C}_{28}$ and $\mathrm{C}_{29}$ regular steranes in saturate hydrocarbon fraction of source rocks in the Gulong and Qijia sags

expulsion thresholds during the period of the first uplift. In addition, the thermal evolution degree of the source rocks in the Gulong sag is obviously higher than that in the Qijia sag, which suggests that the source rocks in the Qijia sag started to generate and discharge hydrocarbon much later than those in the Gulong sag. The differences in the evolution history and degree of thermal evolution of the source rocks in the two depressions may have led to differences in hydrocarbons supplied to the Western Slope.

The hydrocarbon generation and expulsion thresholds of source rocks in the Gulong and Qijia sags are based on the $R_{\mathrm{o}}$ values of $0.5 \%$ and $0.75 \%$, respectively. According to the depth profiles of $100 \times S_{1} /$ TOC and chloroform asphalt "A"/TOC (Figs. 12 and 13), the source rocks in the Gulong and Qijia sags have generally crossed the hydrocarbon generation threshold. However, only the Qing I source rocks have crossed the oil expulsion threshold and reached the oil generation peak. The Nen I source rocks lie close to the oil expulsion threshold but have failed to achieve effective hydrocarbon expulsion. In addition, the highest chloroform asphalt "A"/TOC ratio of the Gulong source rocks is 0.6, whereas that of the Qijia source rocks is lower, with a value of 0.4 (Figs. 12 and 13). These values show that the conversion rate of the Gulong source rocks is high and that that of the Qijia source rocks is relatively low.

In summary, the comparison of the geochemical characteristics of the source rocks indicates that the Qing I member, especially in the Gulong sag, is the main source rock with a high conversion rate supplying oils to the Western
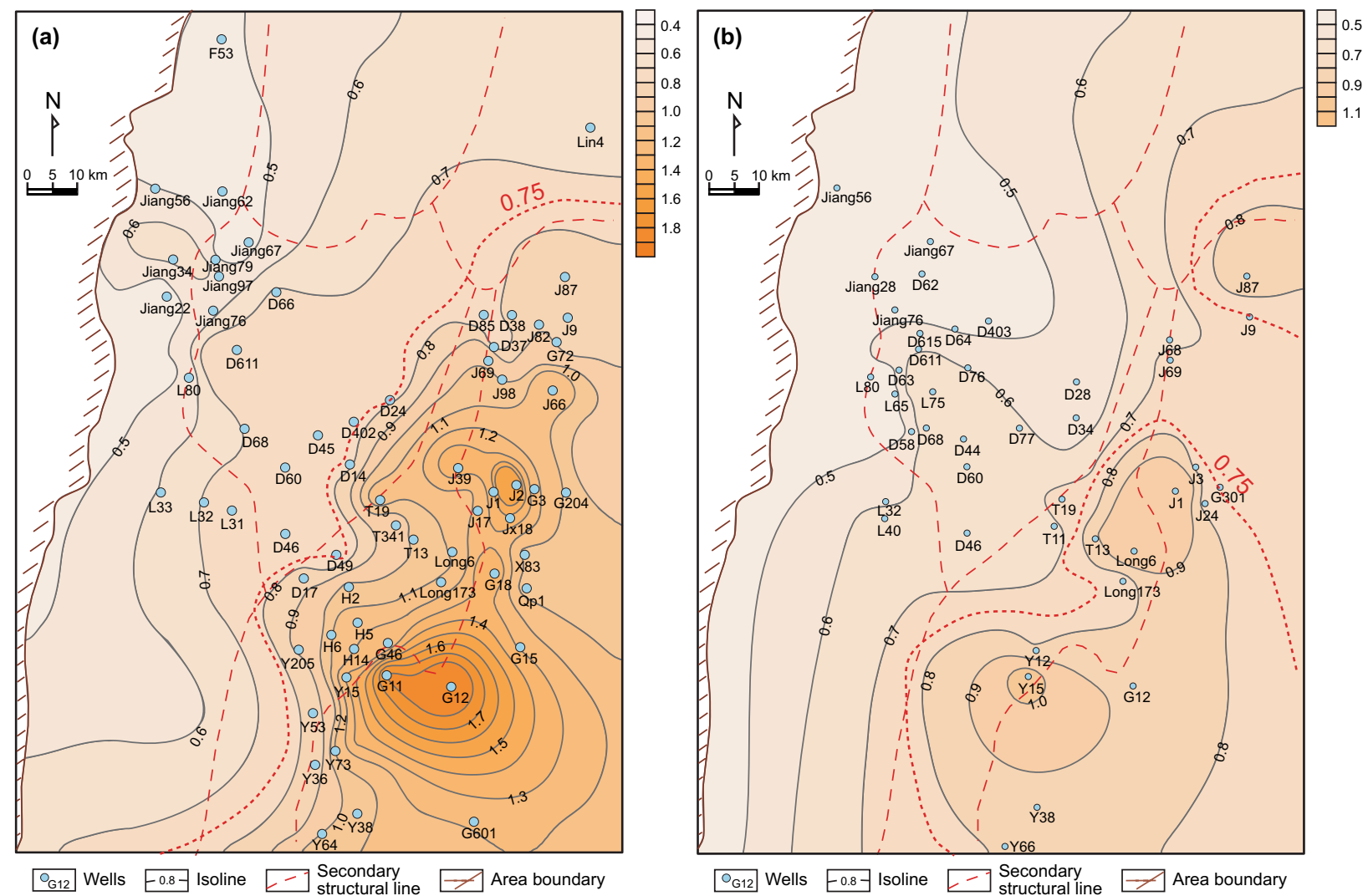

Fig. 8 Planar $R_{\mathrm{o}}$ distribution maps of the (a) Qing I and (b) Nen I source rocks in the study area 
Slope of the northern Songliao Basin and represents the most important hydrocarbon generation and expulsion center.

\subsubsection{Source-source correlation}

The differences in provenance, maturity, and generation of the organic matter and in the expulsion evolution of the source rocks in the Gulong and Qijia sags are responsible for the differences in hydrocarbon generation. In addition, the comparison of the characteristics of biomarkers in the source rocks in the Gulong and Qijia sags can also intuitively reflect the differences between these areas. Therefore, tricyclic terpanes, hopances, pregnane, and $\mathrm{C}_{27}, \mathrm{C}_{28}$, and $\mathrm{C}_{29}$ regular steranes are selected for comparison of the biomarkers in the source rocks in the Gulong and Qijia sags.

According to the distribution characteristics of the terpanes, tricyclic terpanes are widely distributed in the extracts from the source rock and are generally dominated by $\mathrm{C}_{19}-\mathrm{C}_{30}$ terpanes. It can be seen from the $\mathrm{m} / \mathrm{z} 191$ mass chromatograms of the source rock samples from the two sags that the main differences between the source rocks in the two areas are associated with the tricyclic terpanes. The content of tricyclic terpanes of the Gulong source rocks is high (Fig. 14). The main peak corresponds to $\mathrm{C}_{21}$ tricyclic terpane, showing an obvious predominance of $\mathrm{C}_{21}$ tricyclic terpane. The Ts hopance contents are relatively higher than Tm hopance of Gulong source rocks, showing predominance of Ts hopane. Qijia source rocks have low contents of tricyclic terpanes and relative equilibrium between Ts and Tm hopances contents (Fig. 15). The terpane distributions suggest that the source rocks in Gulong sag are more mature than those in Qijia sag.

The distribution characteristics of sterane compounds can be seen in the $\mathrm{m} / \mathrm{z} 217$ mass chromatogram. By comparing the $\mathrm{m} / \mathrm{z} 217$ mass chromatograms of the source rock samples from the two sags, it is found that the main differences between the two sets of source rocks are in the concentrations of $\mathrm{C}_{21}$ pregnane, $\mathrm{C}_{27}$ regular sterane, $\mathrm{C}_{28}$ regular sterane and $\mathrm{C}_{29}$ regular sterane. According to the comparison of the sterane distributions of the two source rock regions $(\mathrm{m} / \mathrm{z} 217)$, the content of $\mathrm{C}_{21}$ pregnane in the Gulong source rocks is obviously high (Fig. 16). The $\mathrm{C}_{29}$ regular sterane is relatively more abundant than the $\mathrm{C}_{27}$ regular sterane and the $\mathrm{C}_{28}$ sterane, showing an obvious predominance (Figs. 7 and 16). The $C_{21}$ pregnane content in the Qijia source rock is obviously low (Fig. 17). The content of the $\mathrm{C}_{27}$ regular sterane is obviously higher than that of the $\mathrm{C}_{29}$ regular sterane and the abundance of the $\mathrm{C}_{28}$ sterane is the lowest, showing an obvious predominance of $\mathrm{C}_{27}$ sterane (Figs. 7 and 17).

Therefore, based on the provenance, maturity, generation and expulsion evolution, and biomarkers distribution, the studied source rocks can be separated in two sets. One set is located in the Qing I member in Gulong sag. The other set is the Qing I source rock in Qijia sag.

\subsection{Crude oil geochemistry}

\subsubsection{Physical properties}

The density, viscosity and wax content of crude oils from Western Slope are given in Table 1. Great variations in physical properties of crude oils can be observed in the different rock units. Crude oils from Nen I member are characterized by high density, averaging $0.9020 \mathrm{~g} / \mathrm{cm}^{3}$, high viscosity, averaging $121.8 \mathrm{mPa} \mathrm{s}$, and low wax content, averaging 23.0\%. Crude oils from Yao II-III member are similar by high density, averaging $0.9058 \mathrm{~g} / \mathrm{cm}^{3}$, high viscosity, averaging $140.5 \mathrm{mPa}$, and low wax content, averaging $22.0 \%$. Due to the intense denudation, Yao I member mainly develops in the Longhupao-Da'an terrace. The short migration distance has less effects on crude oils, with lowest density (averaging $0.8459 \mathrm{~g} / \mathrm{cm}^{3}$ ), lowest viscosity (averaging $35.1 \mathrm{mPa} . \mathrm{s}$ ), and highest wax content (averaging 26.9\%). Compared with oils from the
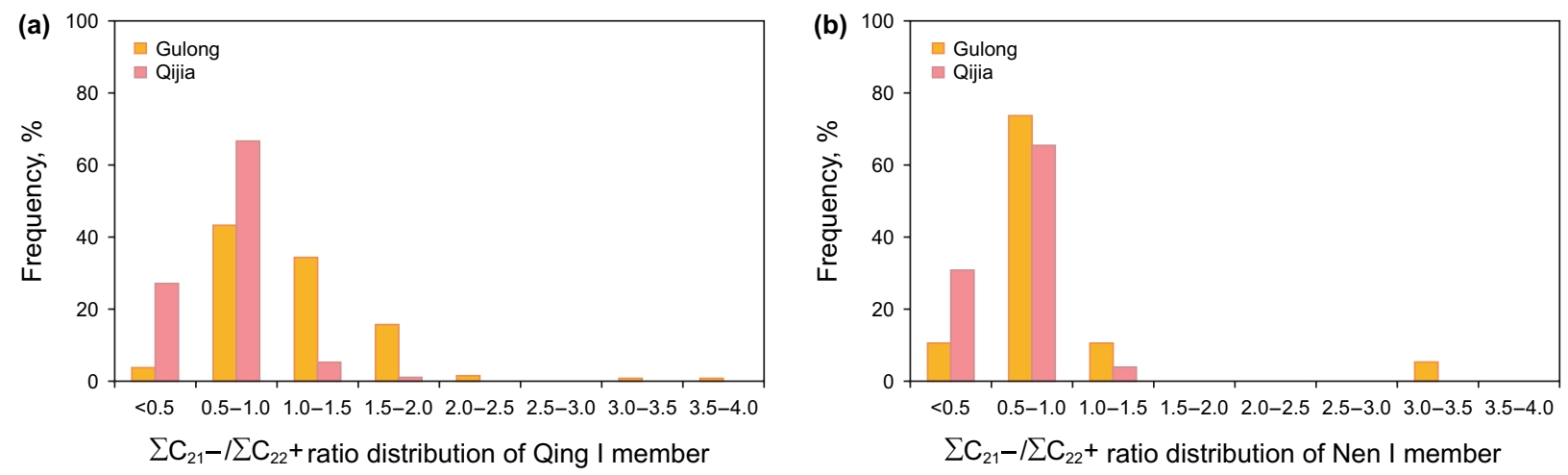

Fig. 9 Frequency distribution of the $\sum \mathrm{C}_{21}{ }^{-} / \sum \mathrm{C}_{22}{ }^{+}$ratio in the (a) Qing I and (b) Nen I source rocks in the Gulong and Qijia sags 


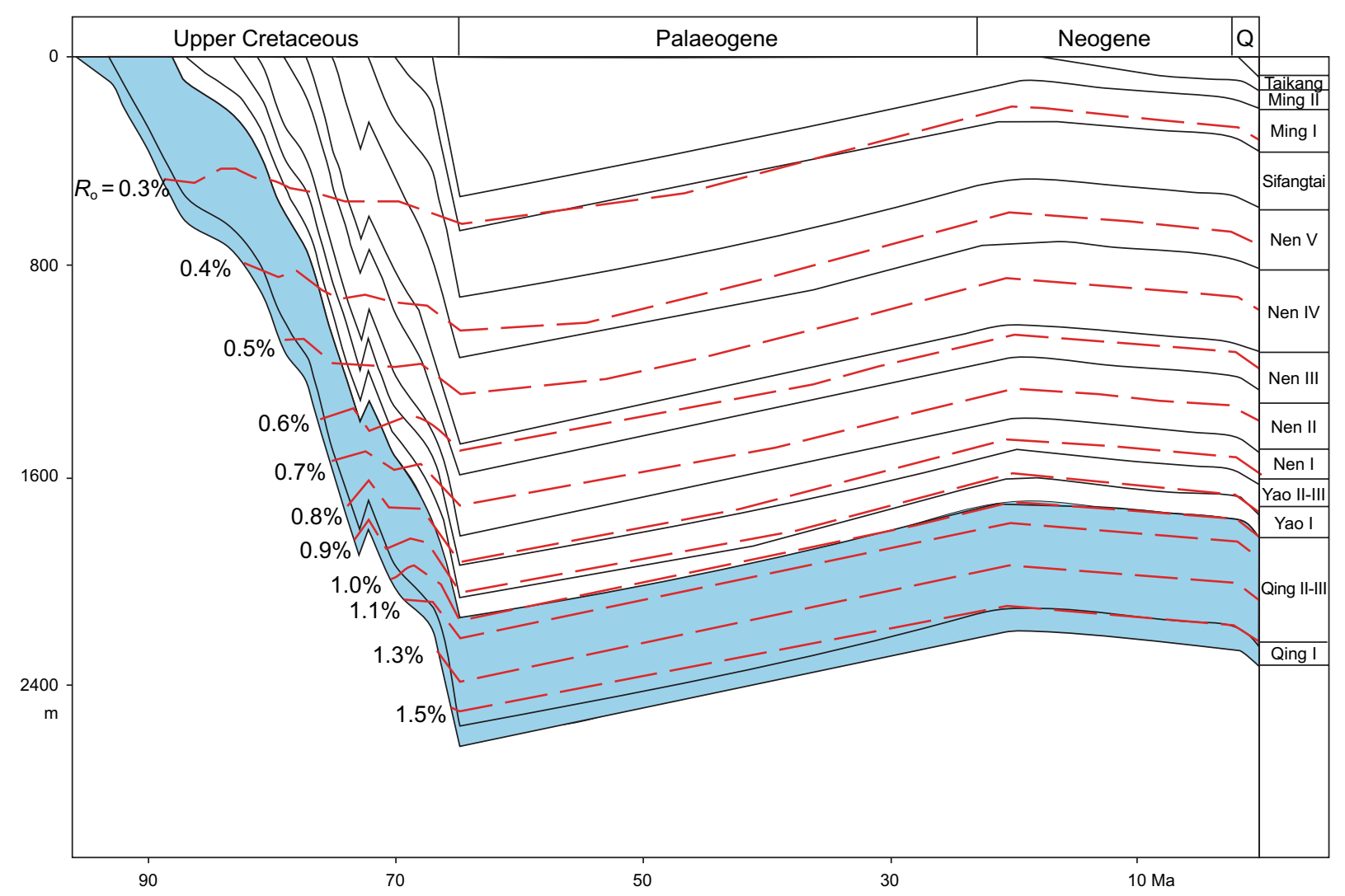

Fig. 10 Burial history and maturity evolution of well G572 in the Gulong sag

overlying Nen I and Yao II-III members, crude oils from Qing II-III member have the relatively lower density with average value of 0.8708 and lower viscosity with average value of 86.8 .

\subsubsection{Gross compositions}

The gross compositions of the oils from the Western Slope are given in Table 2. Saturated hydrocarbon fractions for crude oils range from $47.88 \%$ to $81.40 \%$, with an average of $63.34 \%$ (Table 2). Crude oils are also characterized by high fractions of resins and asphaltenes ranging from $9.26 \%$ to $38.66 \%$, with an average of $24.42 \%$ (Table 2). In view of high density and viscosity, the crude oils might be affected by slight biodegradation.

\subsubsection{Oil maturity}

The maturity of crude oil can be judged by biomarker distributions (Mackenzie 1984). The ratios of $\alpha \alpha \alpha \mathrm{C}_{29} 20 \mathrm{~S} /$ $(20 \mathrm{~S}+20 \mathrm{R})$ and $\mathrm{C}_{29} \beta \beta /(\alpha \alpha+\beta \beta)$ are commonly used indicators for estimation of maturity (Waples and Machihara 1990; Peters and Moldowan 1993; Chen et al. 1997; Peters et al. 2005; $\mathrm{Hu}$ 2012; Bai et al. 2013). Oils from Qing II-III, Yao I and Yao II-III member have $\alpha \alpha \alpha \mathrm{C}_{29} 20 \mathrm{~S} /$
$(20 \mathrm{~S}+20 \mathrm{R})$ sterane ratios ranging from 0.42 to 0.50 and $\mathrm{C}_{29} \beta \beta /(\alpha \alpha+\beta \beta)$ sterane ratios ranging from 0.43 to 0.52 (Table 3 and Fig. 18). Oils from Nen I member have relatively low $\alpha \alpha \alpha \mathrm{C}_{29} 20 \mathrm{~S} /(20 \mathrm{~S}+20 \mathrm{R})$ sterane ratios ranging from 0.37 to 0.44 and relatively low $C_{29} \beta \beta /(\alpha \alpha+\beta \beta)$ sterane ratios ranging from 0.28 to 0.35 (Table 3 and Fig. 18). These results indicate that the crude oils from Western Slope are mature and that there are no immature and low-maturity oil mixes (Fig. 18).

More detailed information about the mature crude oils from different rock units can be provided by hopane parameters, which are sensitive to change in thermal maturity. $T_{\mathrm{s}} /\left(T_{\mathrm{s}}+T_{\mathrm{m}}\right)$ and $\mathrm{C}_{29} T_{\mathrm{s}} / \mathrm{C}_{29}$ hopane ratios are reliable maturity indicators increasing with maturity (Fowler and Brooks 1990; Farrimond et al. 1996; Peters et al. 2005; Cheng et al. 2013; Dong et al. 2015). As shown in Table 3, crude oils from Nen I member have low $T_{\mathrm{s}} /\left(T_{\mathrm{s}}+T_{\mathrm{m}}\right)$ and $\mathrm{C}_{29} T_{\mathrm{s}} / \mathrm{C}_{29}$ hopane ratios, ranging from $0.45-0.51$ and $0.30-0.41$, respectively. Crude oils from Yao II-III, Yao I and Qing II-III have high $T_{\mathrm{s}} /\left(T_{\mathrm{s}}+T_{\mathrm{m}}\right)$ $(0.57-0.66,0.54-0.63$ and $0.58-0.68$, respectively) and $\mathrm{C}_{29} T_{\mathrm{s}} / \mathrm{C}_{29}$ hopane ratios $(0.61-1.10,0.63-0.87$ and $0.67-1.18$, respectively). These indicate that maturity of Nen I oils is lower than that of oils from Yao II-III, Yao I and Qing II-III. 


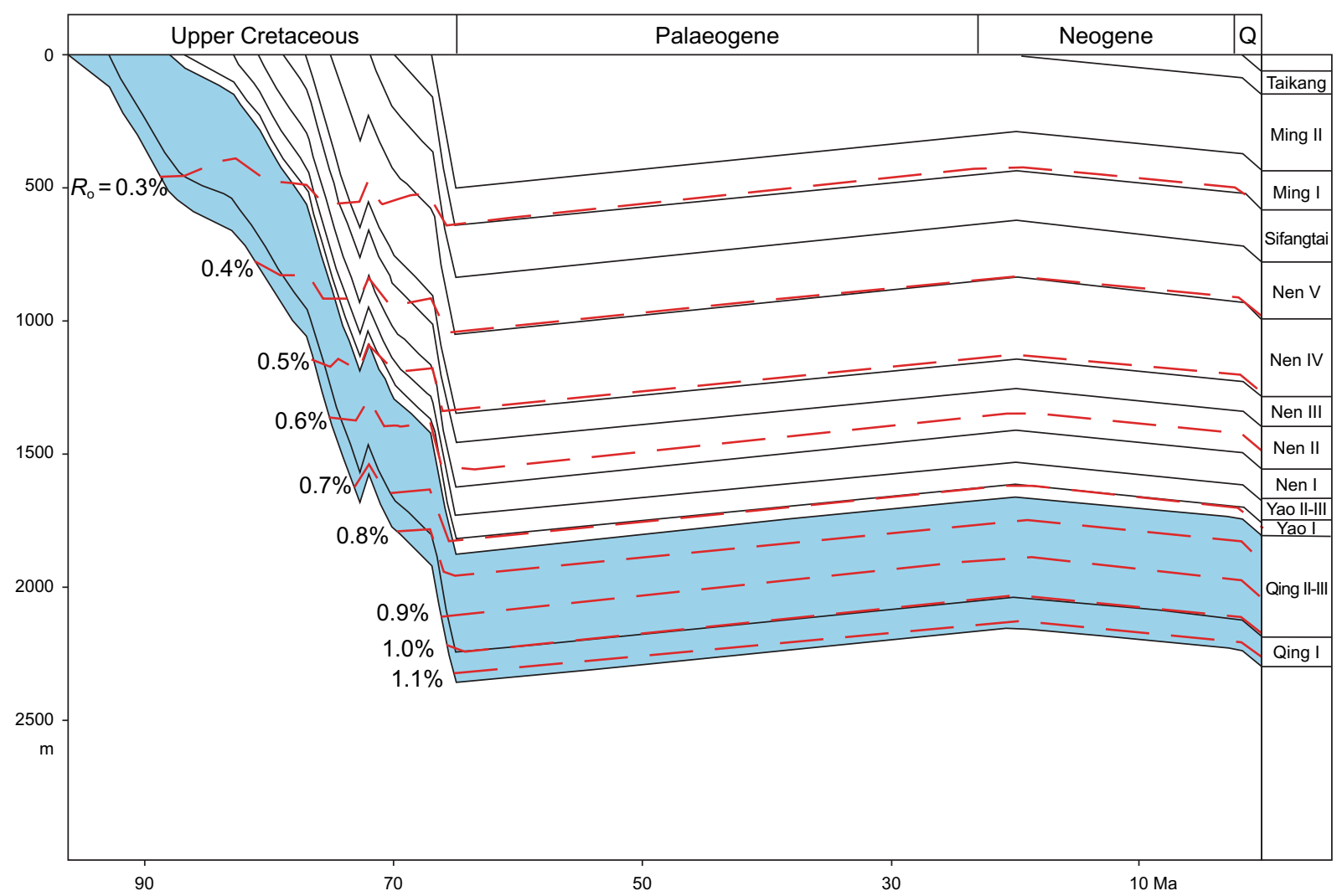

Fig. 11 Burial history and maturity evolution of well G3 in the Qijia sag

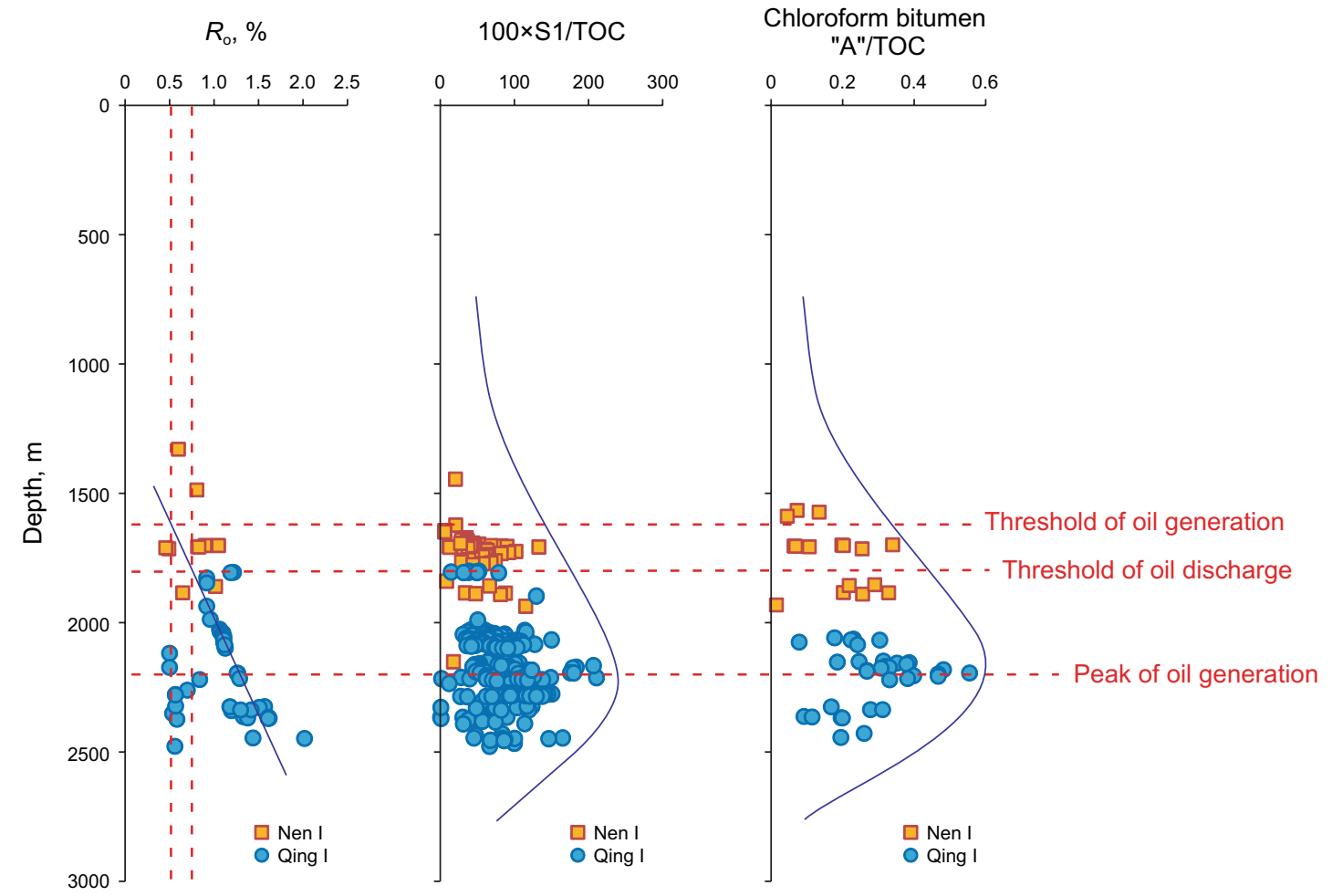

Fig. 12 Hydrocarbon evolution profiles of the source rocks in the Gulong sag 


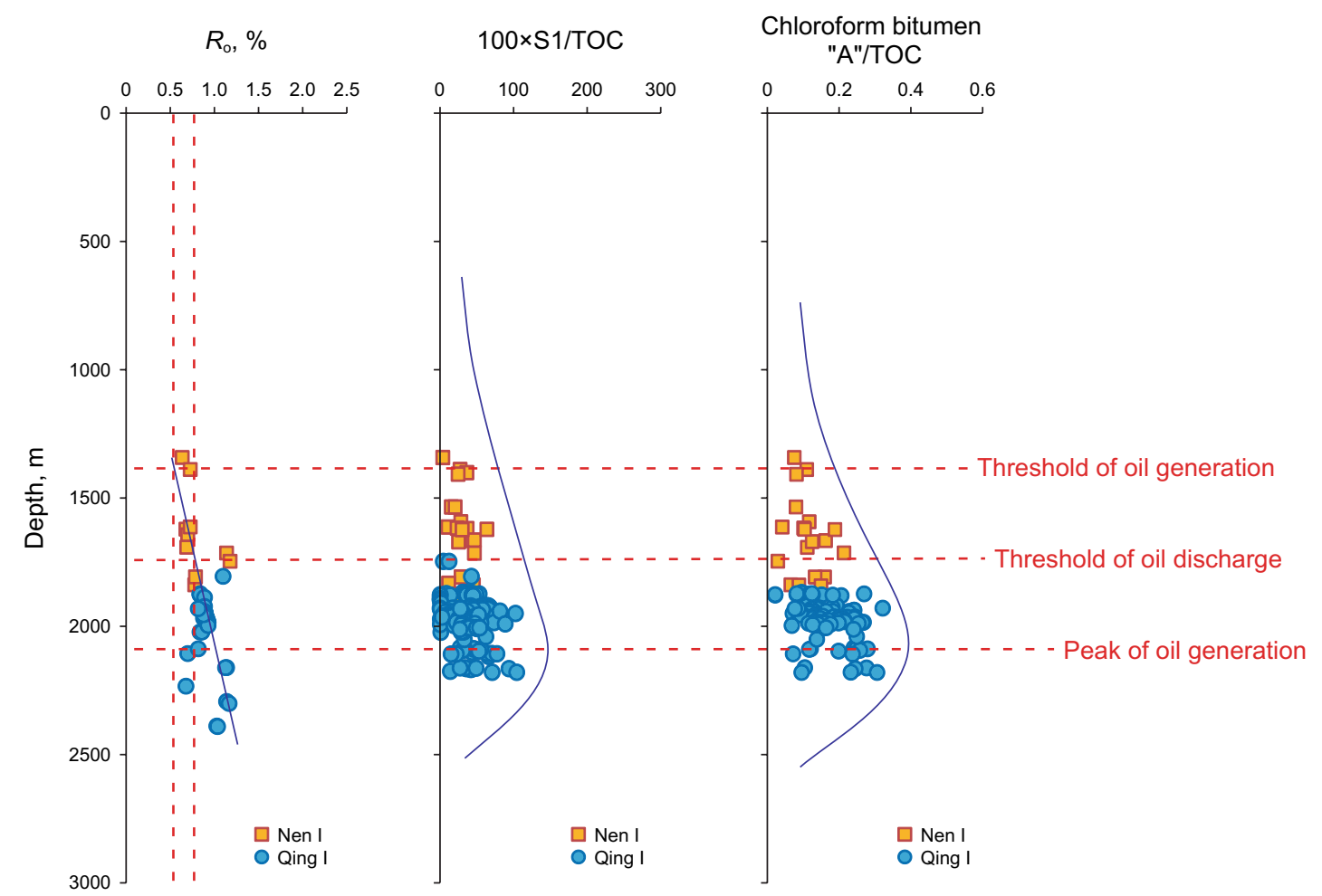

Fig. 13 Hydrocarbon evolution profiles of the source rocks in the Qijia sag
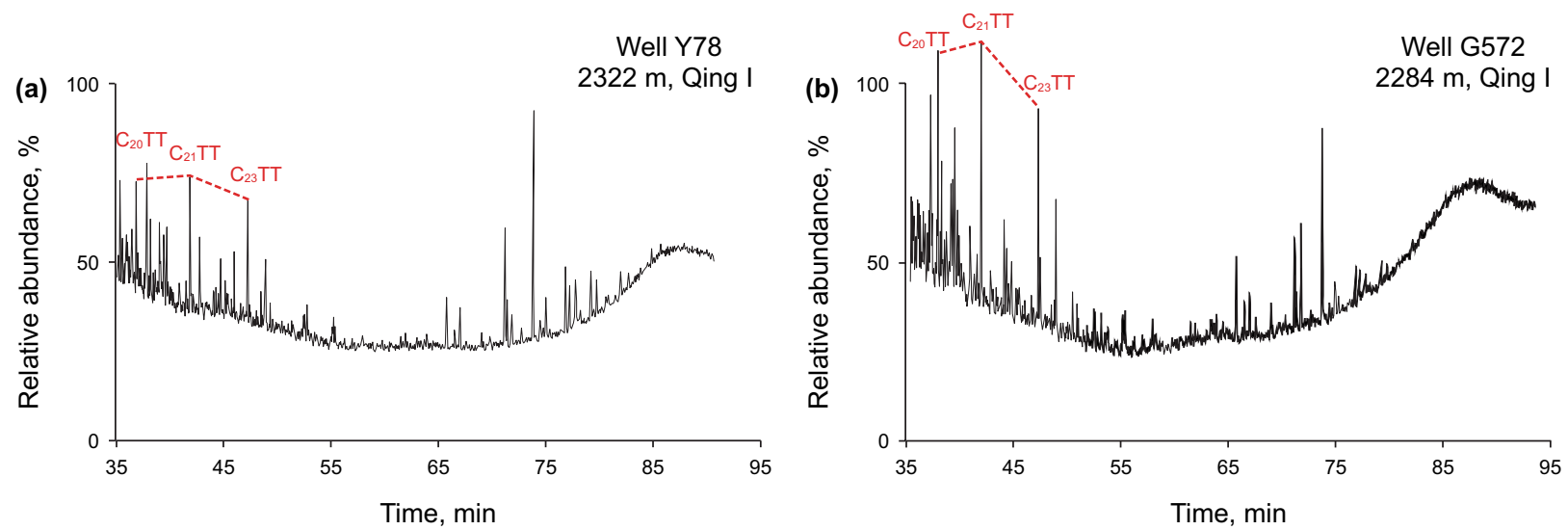

Fig. 14 Terpane distributions (m/z 191) in the source rocks in the Gulong sag

\subsubsection{Oil-oil correlation}

The distribution characteristics of tricyclic terpanes in the Qing II-III, Yao I and Yao II-III crude oils are significantly different from those in the Nen I crude oils (Fig. 19). The contents of tricyclic terpanes are high in the crude oils of Qing II-III, Yao I and Yao II-III members. The main peak corresponds to the $\mathrm{C}_{21}$ tricyclic terpane, showing the obvious predominance of the $\mathrm{C}_{21}$ tricyclic terpane. Qing II-III, Yao I and Yao II-III oils have relatively higher $T_{\mathrm{s}}$ hopance contents than $T_{\mathrm{m}}$ hopance contents, showing predominance of $T_{\mathrm{s}}$ hopane (Fig. 19a, b, and c). Nen I oils have low contents of tricyclic terpanes and relative equilibrium between $T_{\mathrm{s}}$ and $T_{\mathrm{m}}$ hopances contents (Fig. 19d). The terpane distributions suggest that crude oils in Qing II-III, Yao I and Yao II-III members are more mature than those in Nen I member.

The abundance of steranes in m/z 217 mass fragmentograms is also used to differentiate crude oils. The sterane distributions of the Qing II-III, Yao I and Yao II-III crude oils are similar and have relatively high $\mathrm{C}_{21}$ pregnane contents (Fig. 20a, b, and c). The $\mathrm{C}_{27}, \mathrm{C}_{28}$ and $\mathrm{C}_{29}$ regular steranes are characterized by low $\mathrm{C}_{27}$ sterane and a predominance of 

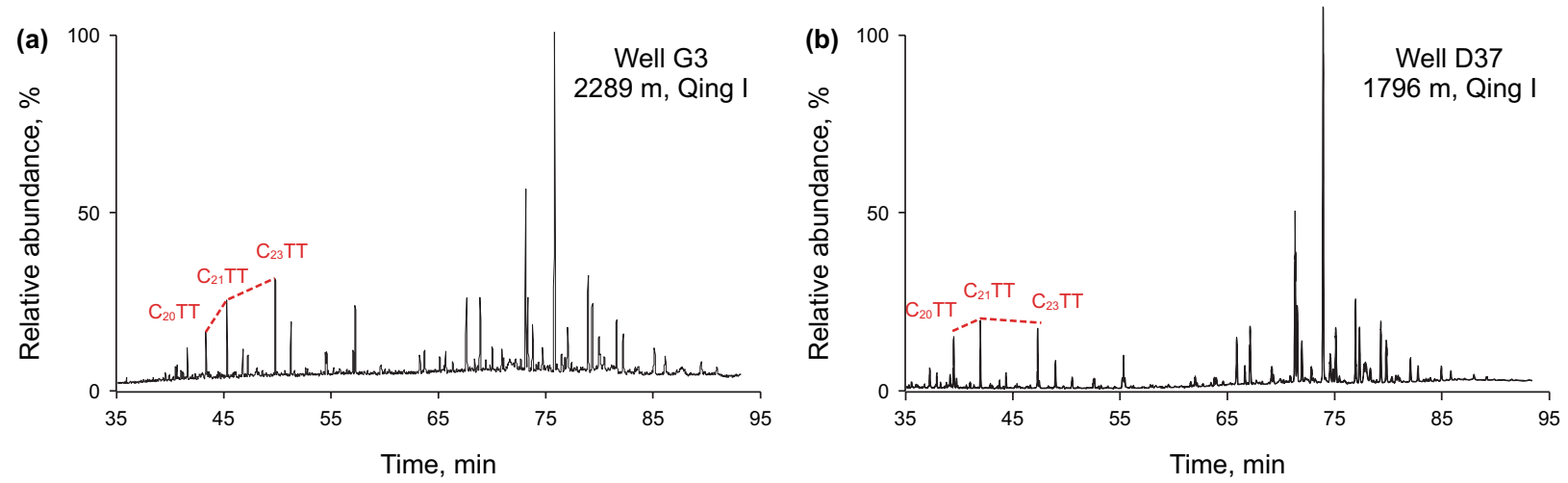

Fig. 15 Terpane distributions (m/z 191) in the source rocks in the Qijia sag
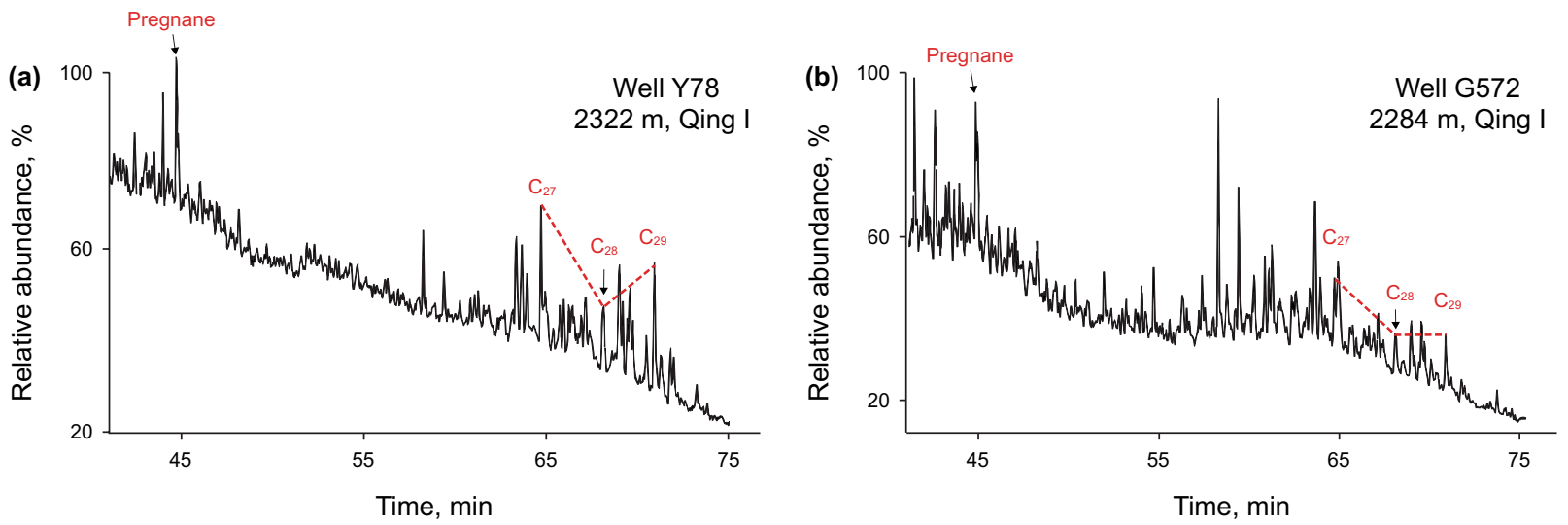

Fig. 16 Sterane distributions (m/z 217) in the source rocks in the Gulong sag
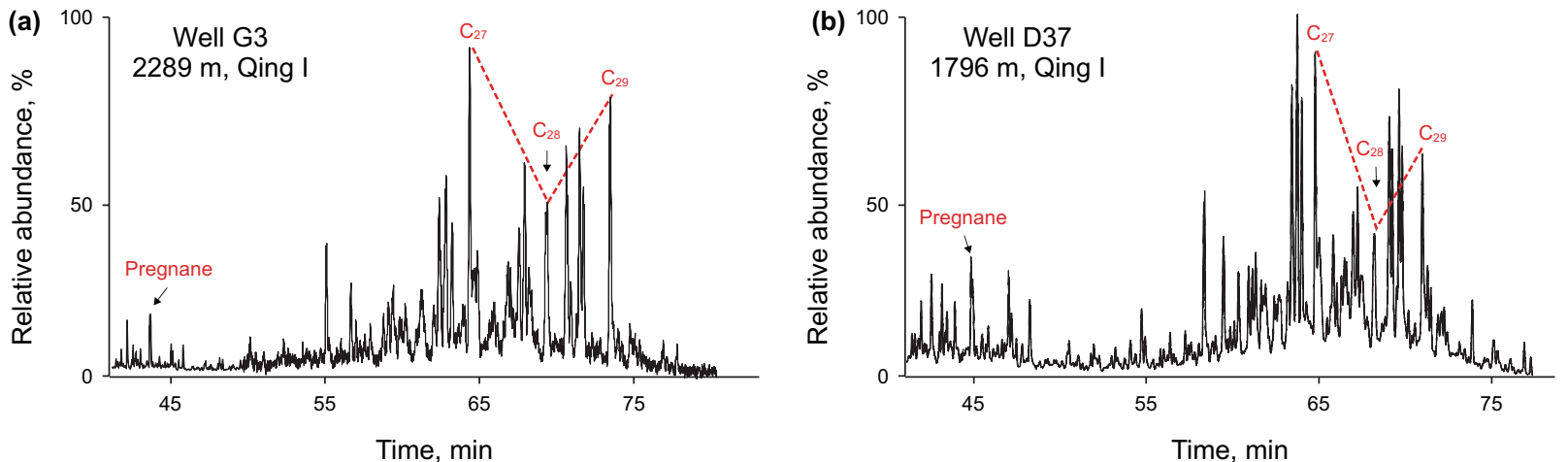

Fig. 17 Sterane distributions (m/z 217) in the source rocks in the Qijia sag

$\mathrm{C}_{29}$ sterane contents $\left(\mathrm{C}_{29}>\mathrm{C}_{28}>\mathrm{C}_{27}\right)$ (Table 3 and Fig. 21). The sterane distributions of the Nen I crude oils are different and features lower $\mathrm{C}_{21}$ pregnane contents (Fig. 20d). The $\mathrm{C}_{27}, \mathrm{C}_{28}$ and $\mathrm{C}_{29}$ regular steranes are characterized by low $\mathrm{C}_{28}$ sterane and a predominance of $\mathrm{C}_{27}$ sterane contents $\left(\mathrm{C}_{27}>\mathrm{C}_{29}>\mathrm{C}_{28}\right)$ (Table 3 and Fig. 21). The different sterane distributions of the two kinds of oils may be related to differences between their kerogen precursors.

Based on the physical properties, gross compositions, maturity and molecular compound, the crude oils are classified into two groups. Group I oils consist of oils from Qing II-III, Yao I and Yao II-III members. Group II oils consist of oils from Nen I member. The oils with systematic variations 
Table 1 Statistics on physical properties of crude oils from Western Slope

\begin{tabular}{lrrr}
\hline Member & Density, g/cm & Viscosity, mPa.s & Wax, $\%$ \\
\hline Nen I & $\frac{0.8360-0.9382}{0.9020(48)}$ & $\frac{6.7-424.5}{121.8(26)}$ & $\frac{11.5-65.1}{23.0(45)}$ \\
Yao II-III & $\frac{0.8319-0.9389}{0.9058(76)}$ & $\frac{8.9-547.1}{140.5(37)}$ & $\frac{5.4-43.5}{22.0(78)}$ \\
Yao I & $\frac{0.8139-0.9072}{0.8459(48)}$ & $\frac{6.9-113.6}{35.1(28)}$ & $\frac{16.4-48.5}{26.9(49)}$ \\
Qing II-III & $\frac{0.8211-0.9317}{0.8708(93)}$ & $\underline{3.4-842.7}$ & $\frac{10-35.3}{86.8(63)}$ \\
\hline
\end{tabular}

Minimum-maximum

$\overline{\text { Average (sample number) }}$ suggest that oils might produce from the different source rock units.

\subsection{Oil-source correlation}

It is well-known that the organic matter in source rocks cracks into oil and gas under certain temperature and pressure conditions. Subsequently, some of these hydrocarbons undergo primary and secondary migrations to appropriate traps, forming oil and gas reservoirs, whereas the rest remains in the source rocks. Therefore, the extractable components in the source rocks are related to the oil and gas derived from the same source rocks and these two substances share some chemical composition similarities. The similarities and differences in chemical composition among oil and gas from the same and different source rocks are the fundamental basis of oil-source correlation. However, oil

Table 2 Gross composition of the crude oils from Western Slope

\begin{tabular}{|c|c|c|c|c|c|c|}
\hline Well & Depth, m & Member & Saturates, \% & Aromatics, $\%$ & Resins, \% & Asphaltenes, $\%$ \\
\hline D410 & 1036 & Nen I & 72.50 & 7.10 & 17.37 & 3.04 \\
\hline D43 & 1065 & Nen I & 64.54 & 15.69 & 19.51 & 0.26 \\
\hline D46 & 1045.75 & Nen I & 67.15 & 16.30 & 16.55 & - \\
\hline D52 & 810 & Nen I & 54.81 & 6.59 & 38.16 & 0.45 \\
\hline D53 & 1063.4 & Nen I & 53.43 & 14.29 & 32.28 & - \\
\hline D610 & 720 & Nen I & 59.50 & 7.29 & 33.21 & - \\
\hline D67 & 752 & Nen I & 68.42 & 8.90 & 21.29 & 1.40 \\
\hline D77 & 1027.3 & Nen I & 67.80 & 14.06 & 18.15 & - \\
\hline D20 & 1250.37 & Yao II-III & 63.44 & 12.09 & 24.46 & - \\
\hline D209 & 1272 & Yao II-III & 68.46 & 10.67 & 20.52 & 0.35 \\
\hline D43 & 1094.6 & Yao II-III & 63.19 & 14.00 & 22.82 & - \\
\hline D46 & 1070.37 & Yao II-III & 63.34 & 16.56 & 20.10 & - \\
\hline D77 & 1052.5 & Yao II-III & 64.88 & 12.64 & 21.09 & 1.39 \\
\hline F722 & 455 & Yao II-III & 47.88 & 13.69 & 35.55 & 2.88 \\
\hline Jiang54 & 484 & Yao II-III & 63.14 & 12.42 & 24.13 & 0.31 \\
\hline L27 & 676 & Yao II-III & 47.89 & 23.72 & 27.70 & 0.69 \\
\hline D209 & 1341.5 & Yao I & 66.03 & 6.23 & 27.74 & - \\
\hline D46 & 1085.57 & Yao I & 63.61 & 20.58 & 15.58 & 0.24 \\
\hline Long68 & 1762.98 & Yao I & 81.40 & 9.03 & 9.58 & - \\
\hline T30 & 1039 & Yao I & 80.58 & 10.15 & 9.26 & - \\
\hline T6 & 1245.85 & Yao I & 74.83 & 7.62 & 17.30 & 0.25 \\
\hline D20 & 1404 & Qing II-III & 56.18 & 15.43 & 26.98 & 1.41 \\
\hline D209 & 1626 & Qing II-III & 72.55 & 7.47 & 19.98 & - \\
\hline D21 & 1450 & Qing II-III & 61.69 & 12.22 & 26.09 & - \\
\hline D410 & 1115 & Qing II-III & 59.11 & 11.24 & 29.66 & - \\
\hline D420 & 1106 & Qing II-III & 60.48 & 20.08 & 19.44 & - \\
\hline D610 & 770 & Qing II-III & 49.32 & 12.02 & 38.66 & - \\
\hline Jiang 37 & 596 & Qing II-III & 62.81 & 11.92 & 25.28 & - \\
\hline Jiang55 & 466 & Qing II-III & 49.49 & 12.04 & 35.27 & 3.20 \\
\hline L27 & 687 & Qing II-III & 58.27 & 14.17 & 27.56 & - \\
\hline T6 & 1300 & Qing II-III & 76.70 & 3.48 & 19.39 & 0.44 \\
\hline
\end{tabular}


and gas can be contaminated in the process of migration and accumulation, which increases the difficulty of oil-source correlation to some extent. Therefore, we need to conduct a comprehensive comparative analysis of various parameters and select specific and stable parameters for oil-source correlation.

A successful oil-source rock correlation aims to find the genetic relationship between source rocks and oils and relies on biomarker composition (Peters and Moldowan 1993; Peters et al. 2005; Curiale 2008). As discussed earlier, based on the physical properties, chemical compositions, and biomarker fingerprints, the investigated oils from the Western Slope belong to group I and II. The Qing I member in the both Gulong and Qijia source rocks with different characteristics are considered be effective sources for the oils. Based on the m/z 191 and m/z 217 mass chromatograms, the crude oil to source rock correlation is discussed in order to determine genetic relationships.

\subsubsection{Group I oils}

Terpane parameters that can be used to perform oil-source rock correlation. Group I oils have high abundance in tricyclic terpanes and show obvious predominance of the $\mathrm{C}_{21}$ tricyclic terpane. The $T_{\mathrm{s}}$ hopance contents are higher than $\mathrm{Tm}$ hopance, revealing predominance of $T_{\mathrm{s}}$ hopane. Additionly, $T_{\mathrm{s}} /\left(T_{\mathrm{s}}+T_{\mathrm{m}}\right)$ and $\mathrm{C}_{29} T_{\mathrm{s}} / \mathrm{C}_{29}$ hopane ratios for group I oils are relatively high, suggesting relatively high maturity. The Gulong source rock extracts have the similar characteristics of terpane parameters, indicating group I oils are related.

Table 3 Molecular parameters of crude oils

\begin{tabular}{|c|c|c|c|c|c|c|c|c|c|c|}
\hline Well & Depth, m & Member & Group & $\begin{array}{l}\alpha \alpha \alpha \mathrm{C}_{29} \\
20 \mathrm{~S} / \\
(20 \mathrm{~S}+20 \mathrm{R})\end{array}$ & $\mathrm{C}_{29} \beta \beta(\beta \beta+\alpha \alpha)$ & $T_{\mathrm{s}} /\left(T_{\mathrm{s}}+T_{\mathrm{m}}\right)$ & $\begin{array}{l}\mathrm{C}_{29} T_{\mathrm{s}} / \\
\mathrm{C}_{29} \\
\text { hopane }\end{array}$ & $\mathrm{C}_{27} / \sum \mathrm{C}_{27-29}$ & $\mathrm{C}_{28} / \sum \mathrm{C}_{27-29}$ & $\mathrm{C}_{29} / \sum \mathrm{C}_{27-29}$ \\
\hline D410 & 1036 & Nen I & II & 0.40 & 0.28 & 0.45 & 0.30 & 41.33 & 23.68 & 34.99 \\
\hline D43 & 1065 & Nen I & II & 0.43 & 0.33 & 0.49 & 0.39 & 37.76 & 23.8 & 38.44 \\
\hline D46 & 1045.75 & Nen I & II & 0.37 & 0.32 & 0.47 & 0.33 & 41.64 & 23.2 & 35.16 \\
\hline D52 & 810 & Nen I & II & 0.40 & 0.35 & 0.48 & 0.39 & 39.75 & 24.16 & 36.09 \\
\hline D53 & 1063.4 & Nen I & II & 0.44 & 0.34 & 0.47 & 0.32 & 39.63 & 24.82 & 35.55 \\
\hline D610 & 720 & Nen I & II & 0.38 & 0.31 & 0.50 & 0.39 & 42.45 & 24.19 & 33.36 \\
\hline D67 & 752 & Nen I & II & 0.38 & 0.31 & 0.51 & 0.41 & 41.4 & 24.22 & 34.38 \\
\hline D77 & 1027.3 & Nen I & II & 0.42 & 0.28 & 0.45 & 0.30 & 38.98 & 24.56 & 36.46 \\
\hline D20 & 1250.37 & Yao II-III & I & 0.44 & 0.44 & 0.57 & 0.75 & 25.67 & 32.41 & 41.93 \\
\hline D209 & 1272 & Yao II-III & I & 0.44 & 0.45 & 0.66 & 1.10 & 27.36 & 31.82 & 40.82 \\
\hline D43 & 1094.6 & Yao II-III & I & 0.45 & 0.43 & 0.66 & 1.06 & 24.02 & 33.4 & 42.58 \\
\hline D46 & 1070.37 & Yao II-III & I & 0.45 & 0.43 & 0.60 & 0.61 & 27.09 & 29.33 & 43.58 \\
\hline D77 & 1052.5 & Yao II-III & I & 0.47 & 0.46 & 0.62 & 0.67 & 28.31 & 30.53 & 41.16 \\
\hline F722 & 455 & Yao II-III & I & 0.45 & 0.49 & 0.59 & 0.64 & 21.66 & 34 & 44.34 \\
\hline Jiang54 & 484 & Yao II-III & I & 0.47 & 0.44 & 0.61 & 0.68 & 27.83 & 30.68 & 41.49 \\
\hline L27 & 676 & Yao II-III & I & 0.43 & 0.46 & 0.62 & 0.83 & 26.07 & 30.69 & 43.25 \\
\hline D209 & 1341.5 & Yao I & I & 0.42 & 0.44 & 0.63 & 0.82 & 24.09 & 30.8 & 45.11 \\
\hline D46 & 1085.57 & Yao I & I & 0.47 & 0.45 & 0.59 & 0.63 & 24.39 & 30.22 & 45.39 \\
\hline Long68 & 1762.98 & Yao I & I & 0.44 & 0.45 & 0.63 & 0.87 & 26.42 & 33.5 & 40.08 \\
\hline T30 & 1039 & Yao I & I & 0.46 & 0.45 & 0.54 & 0.68 & 26.55 & 29.22 & 44.23 \\
\hline T6 & 1245.85 & Yao I & I & 0.46 & 0.44 & 0.61 & 0.75 & 24.32 & 34.09 & 41.59 \\
\hline D20 & 1404 & Qing II-III & I & 0.46 & 0.45 & 0.58 & 0.71 & 22.45 & 32.86 & 44.68 \\
\hline D209 & 1626 & Qing II-III & I & 0.45 & 0.44 & 0.66 & 1.10 & 23.27 & 32.72 & 44.01 \\
\hline D21 & 1450 & Qing II-III & I & 0.46 & 0.45 & 0.59 & 0.75 & 22.01 & 34.18 & 43.81 \\
\hline D410 & 1115 & Qing II-III & I & 0.45 & 0.52 & 0.65 & 0.91 & 22.03 & 33.2 & 44.77 \\
\hline D420 & 1106 & Qing II-III & I & 0.46 & 0.45 & 0.68 & 1.12 & 23.02 & 32.06 & 44.92 \\
\hline D610 & 770 & Qing II-III & I & 0.47 & 0.45 & 0.62 & 0.79 & 25.6 & 31.63 & 42.77 \\
\hline Jiang37 & 596 & Qing II-III & I & 0.47 & 0.44 & 0.61 & 0.67 & 29.97 & 30.35 & 39.68 \\
\hline Jiang55 & 466 & Qing II-III & I & 0.50 & 0.45 & 0.62 & 0.72 & 27.23 & 31.25 & 41.52 \\
\hline L27 & 687 & Qing II-III & I & 0.46 & 0.46 & 0.65 & 1.04 & 25.44 & 30.73 & 43.82 \\
\hline T6 & 1300 & Qing II-III & I & 0.50 & 0.47 & 0.68 & 1.18 & 26.26 & 33.64 & 40.1 \\
\hline
\end{tabular}




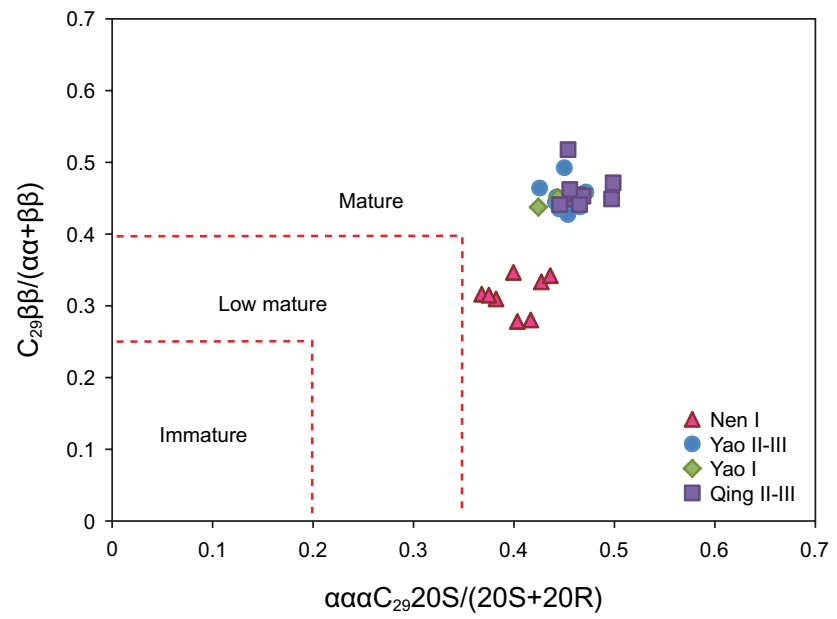

Fig. 18 Sterane isomerization index distribution of crude oils in the Western Slope of Northern Songliao Basin

Group I oils and Gulong source rock are dominated by $\mathrm{C}_{29}$ steranes and have similar distributions of $\mathrm{C}_{27}-\mathrm{C}_{28}-\mathrm{C}_{29}$ steranes $\left(\mathrm{C}_{29}>\mathrm{C}_{28}>\mathrm{C}_{27}\right)$, indicating that they are genetically related. $\mathrm{C}_{29} \beta \beta /(\alpha \alpha+\beta \beta)$ and $\alpha \alpha \alpha \mathrm{C}_{29} 20 \mathrm{~S} /(20 \mathrm{~S}+20 \mathrm{R})$ sterane ratios in group I oils are relatively high, indicating that they were derived from source rocks with maturity relatively high. In terms of the sterane parameters, group I oils correlate with Gulong source rock extracts.

\subsubsection{Group II oils}

Oils from Nen I member, defined as group II, and extracts of source rock from Qijia generally show similar biomarker fingerprints. Group II oils and Qijia source rock extracts have low abundance in tricyclic terpanes and relative equilibrium between $T_{\mathrm{S}}$ and $\mathrm{Tm}$ hopances. In addition, group II oils have low $T_{\mathrm{s}} /\left(T_{\mathrm{s}}+T m\right)$ and $\mathrm{C}_{29} T_{\mathrm{s}} / \mathrm{C}_{29}$ hopane ratios, suggesting the maturity are relatively low.

Group II oils are dominated by $\mathrm{C}_{27}$ steranes and correlated with Qijia source rock extracts which have similar distributions of $\mathrm{C}_{27}-\mathrm{C}_{28}-\mathrm{C}_{29}$ steranes $\left(\mathrm{C}_{27}>\mathrm{C}_{29}>\mathrm{C}_{28}\right)$. Group II oils have low values in $\mathrm{C}_{29} \beta \beta /(\alpha \alpha+\beta \beta)$ and $\alpha \alpha \alpha \mathrm{C}_{29} 20 \mathrm{~S} /$ $(20 \mathrm{~S}+20 \mathrm{R})$ sterane ratios, suggesting that they were derived from source rocks with maturity relatively low. All of these results demonstrate that oils in the Nen I member were mainly derived from Qing I source rock within Qijia sag.

Therefore, based on the geological background, the distribution characteristics of biomarkers and the maturity differences between crude oils and source rocks, it can be concluded that the crude oils in the Qing II-III, Yao I and Yao II-III members were derived from Gulong source rock
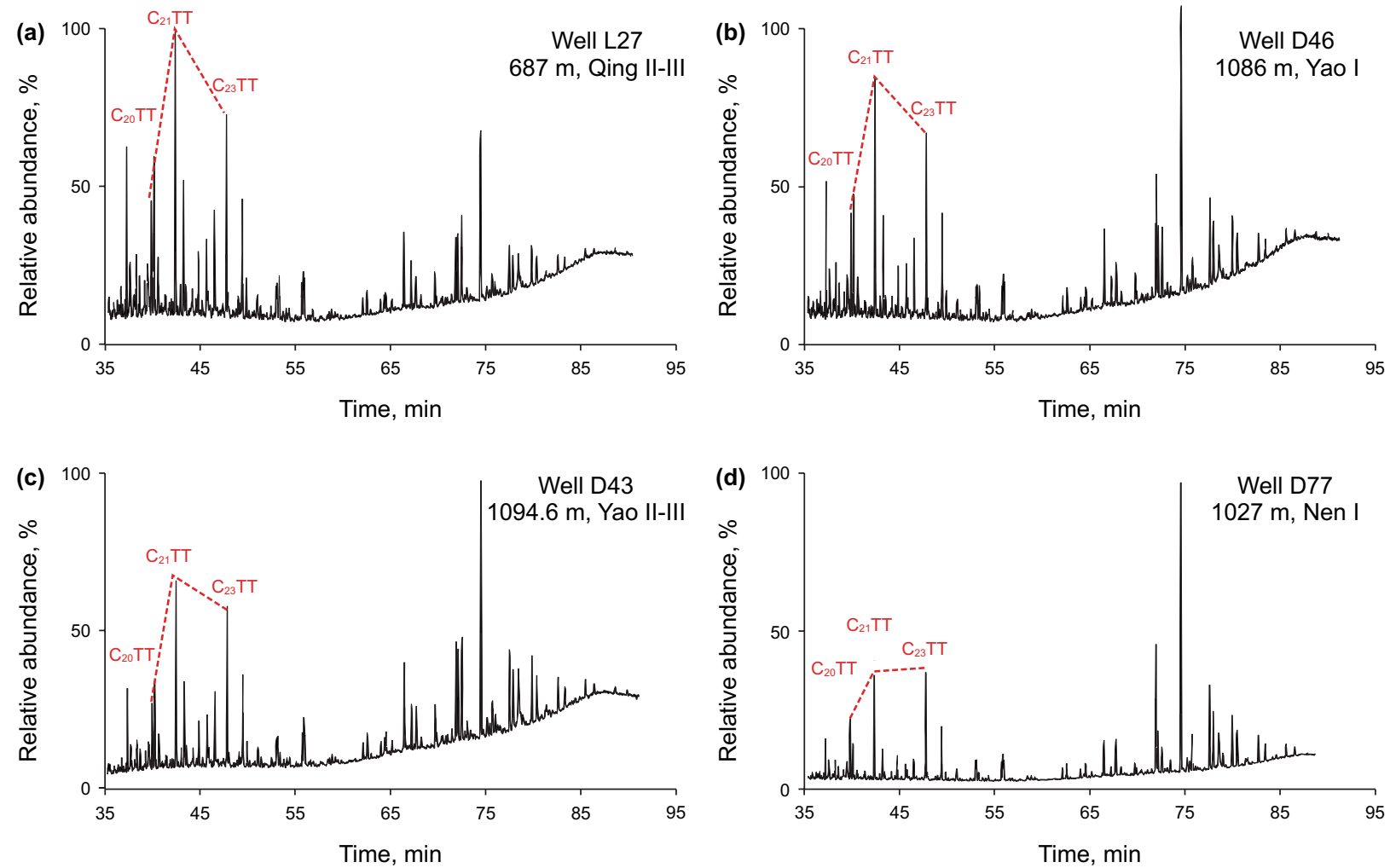

Fig. 19 Terpane distributions ( $\mathrm{m} / \mathrm{z} 191)$ in the oils from different members in the Western Slope 

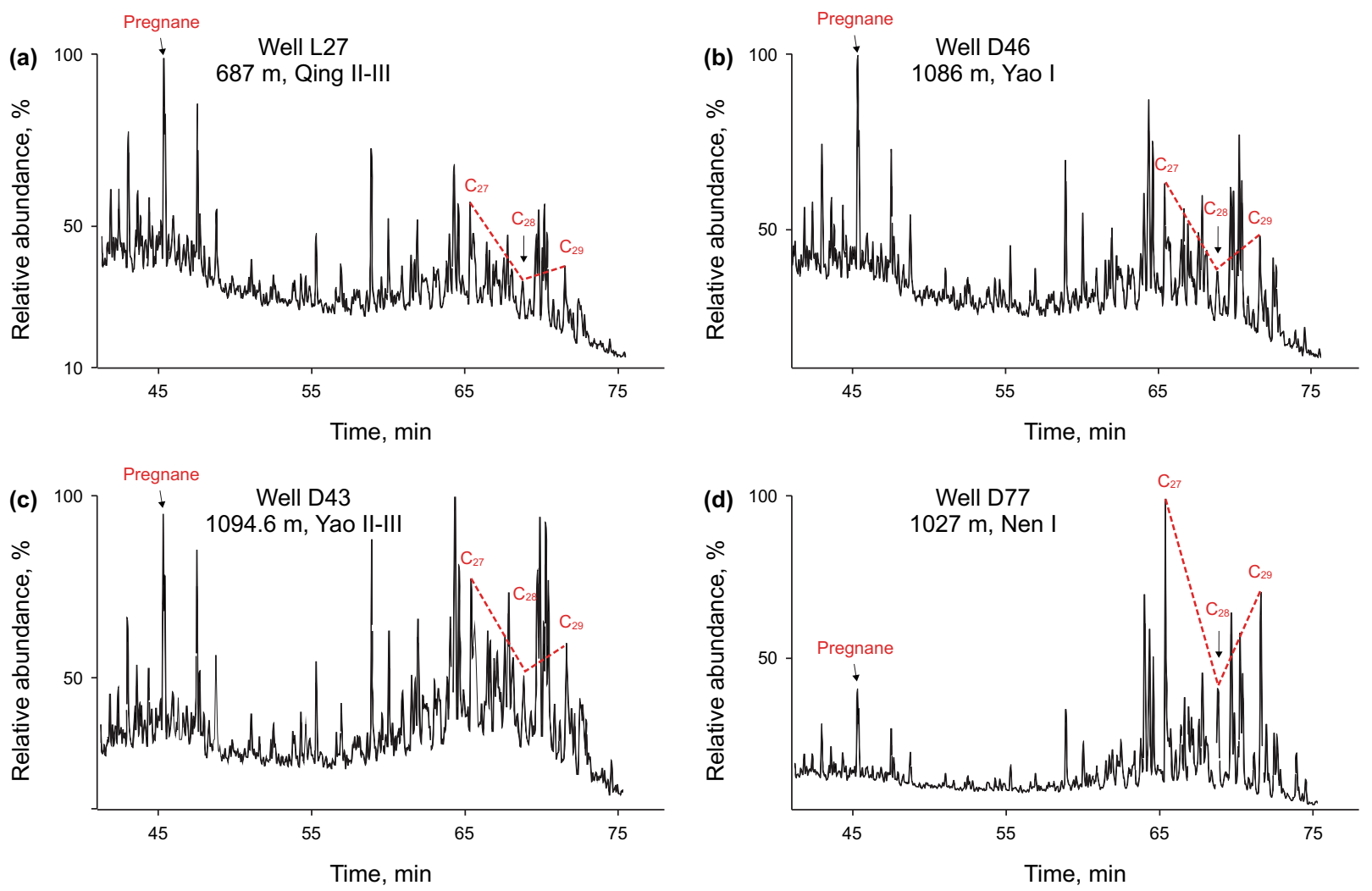

Fig. 20 Sterane distributions (m/z 217) in the oils from different members in the Western Slope

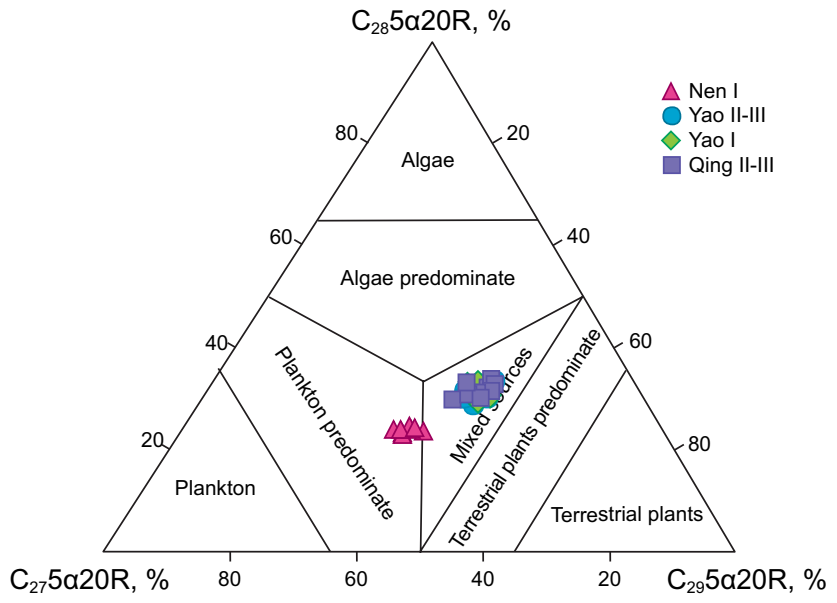

Fig. 21 Ternary diagram showing the relative abundance of $\mathrm{C}_{27}, \mathrm{C}_{28}$ and $\mathrm{C}_{29}$ regular steranes in saturate hydrocarbon fraction of crude oils

and that the crude oils in the Nen I member were derived from Qijia source rocks.

The differences in crude oil sources in the Western Slope are mainly controlled by the differences in source rock development, hydrocarbon expulsion and distribution of migration paths. The differences in organic matter provenance, thermal maturity, generation and expulsion evolution between the Gulong and Qijia source rocks controlled the differences in hydrocarbon generation and expulsion and the important contribution of the Gulong source rocks. The late expulsion of hydrocarbons in the Qijia sag and the existence of surrounding faults formed in the late stage of the deposition of the Mingshui Formation may have led to hydrocarbon migration and accumulation in the sandstone of the Nen I member, resulting in difference and delamination between hydrocarbon sources.

\section{Conclusions}

Multiple geochemical parameters were employed for source rock characteristic analysis, such as organic matter abundance, type, provenance, thermal maturity and saturated hydrocarbon chromatography, to recognize the differences between the Gulong source rocks and the Qijia source rocks. Furthermore, multiple analytical parameters were employed for oil-source correlation, such as molecular characteristics and biomarker fingerprints of source rock extracts and crude oils, to differentiate among the sources. The results and analyses allow the following conclusions: 
(1) The possible source rocks are mainly distributed in the Qing I and Nen I members of Gulong and Qijia sags with a high abundance of organic matter. The organic matter of Gulong source rocks is primarily Type II-III kerogen and derived from mixed sources, while that of Qijia source rocks is mixed Type I-II kerogen and primarily derived from plankton. Gulong source rocks feature a high degree of thermal evolution and a broad range of mature source rocks. The Qing I member in the Gulong sag has the highest thermal maturity. The hydrocarbon evolution profiles indicate that the Qing I source rocks have been the most effective at producing and expelling hydrocarbons, especially in the Gulong sag, where the rocks have a high conversion rate.

(2) Based on physical properties and molecular compositions, crude oils in the target strata are generally classified into two groups. Group I oils exist in the Qing II-III, Yao I, and Yao II-III members with maturity relatively high, while group II oils originate from Nen I member with maturity relatively low.

(3) Great differences in biomarker characteristics exist between the Gulong source rocks and the Qijia source rocks, as primarily evidenced by differences in the distribution characteristics of tricyclic terpanes, hopances, pregnane, and $\mathrm{C}_{27}, \mathrm{C}_{28}, \mathrm{C}_{29}$ regular steranes. Correlations of these biomarker fingerprints between the source rocks and the crude oils suggest that the group I oils from the Qing II-III, Yao I, and Yao II-III members are mainly derived from Gulong source rocks, while group II oils from the Nen I member are derived from Qijia source rocks.

\begin{abstract}
Acknowledgements The authors are grateful to the anonymous reviewers for their constructive comments and suggestions to significantly improve the manuscript. The authors wish to acknowledge the Exploration and Development Research Institute of Daqing Oilfield for providing the cores and experimental data used in this study.
\end{abstract}

Open Access This article is licensed under a Creative Commons Attribution 4.0 International License, which permits use, sharing, adaptation, distribution and reproduction in any medium or format, as long as you give appropriate credit to the original author(s) and the source, provide a link to the Creative Commons licence, and indicate if changes were made. The images or other third party material in this article are included in the article's Creative Commons licence, unless indicated otherwise in a credit line to the material. If material is not included in the article's Creative Commons licence and your intended use is not permitted by statutory regulation or exceeds the permitted use, you will need to obtain permission directly from the copyright holder. To view a copy of this licence, visit http://creativecommons.org/licenses/by/4.0/.

\section{References}

Bai Y, Luo J, Liu X, Ji W, Wang X. Geochemical characteristics of crude oil and oil-source correlation in Yanchang Formation (Upper Triassic) in Wubao Area, Ordos Basin. Acta Sedimentol Sinica. 2013;31(2):374-83. https://doi.org/10.14027/j.cnki. cjxb.2013.02.009.

Bennett B, Fustic M, Farrimond P, Huang H, Larter SR. 25-norhopanes: formation during biodegradation of petroleum in the subsurface. Org Geochem. 2006;37(7):787-97. https://doi. org/10.1016/j.orggeochem.2006.03.003.

Bi H, Li J, Tang Z, Li P, Wang L, Shang X. High-resolution sequence stratigraphy sedimentology and reservoir quality evaluation of the Yaojia Formation in the Longxi area of the Western Slope Songliao Basin. China Mar Pet Geol. 2017;88:511-30. https:// doi.org/10.1016/j.marpetgeo.2017.09.004.

Brito M, Rodrigues R, Baptista R, Duarte LV, Azeredo AC, Jones CM. Geochemical characterization of oils and their correlation with Jurassic source rocks from the Lusitanian Basin (Portugal). Mar Pet Geol. 2017;85:151-76. https://doi.org/10.1016/j.marpe tgeo.2017.05.010.

Brooks JD, Gould K, Smith JW. Isoprenoid hydrocarbons in coal and petroleum. Nature. 1969;222(5190):257-9. https://doi. org/10.1038/222257a0.

Cai C, Li K, Anlai M, Zhang C, Chen L. Distinguishing cambrian from upper ordovician source rocks: evidence from sulfur isotopes and biomarkers in the Tarim Basin. Org Geochem. 2009;40(7):75568. https://doi.org/10.1016/j.orggeochem.2009.04.008.

Chen J, Liu C, Zhang S, Bi Y, Bi Y. Composition of the biomarkers in crude oil is the reflection of pool-forming history. Earth Sci J China Univ Geosci. 1997;22(6):97-102 (in Chinese).

Cheng P, Xiao XM, Tian H, Huang BJ, Wilkins RWT, Zhang YZ. Source controls on geochemical characteristics of crude oils from the Qionghai Uplift in the western Pearl River Mouth Basin offshore South China Sea. Mar Pet Geol. 2013;40:85-98. https://doi. org/10.1016/j.marpetgeo.2012.10.003.

Curiale JA. Oil-source rock correlations-limitations and recommendations. Org Geochem. 2008;39:1150-61. https://doi.org/10.1016/j. orggeochem.2008.02.001.

Dong T, He S, Liu G, Hou Y, Harris NB. Geochemistry and correlation of crude oils from reservoirs and source rocks in southern Biyang Sag Nanxiang Basin China. Org Geochem. 2015;80:1834. https://doi.org/10.1016/j.orggeochem.2014.12.006.

Dow WG. Application of oil correaltion and source rock data to exploration in Williston Basin. AAPG Bulletin. 1974;58:125362. https://doi.org/10.1306/819A3F00-16C5-11D7-8645000102 C1865D.

Diasty WSE, Beialy SYE, Attar RME, Khairy A, Batten DJ. Oil-source correlation in the West Esh El Mellaha southwestern margin of the Gulf of Suez rift Egypt. J Petrol Sci Eng. 2019;180:844-60. https://doi.org/10.1016/j.petrol.2019.05.083.

Farrimond P, Bevan JC, Bishop AN. Hopanoid hydrocarbon maturation by an igneous intrusion. Org Geochem. 1996;25:149-64. https:// doi.org/10.1016/S0146-6380(96)00128-3.

Feng Z, Huang C, Sun Y, Wang X, Sun C. Distribution of oxygenated compounds in oils from the west slope of Songliao Basin. Pet Exploration Dev. 2005;32(3):48-50. https://doi.org/10.1016/j. molcatb.2005.02.001.

Fowler MG, Brooks PW. Organic geochemistry as an aid in the interpretation of the history of oil migration into different reservoirs at the Hibernia K-18 and Ben Nevis I-45 wells Jeanne d'Arc Basin offshore eastern Canada. Org Geochem. 1990;16:461-75. https:// doi.org/10.1016/0146-6380(90)90062-5.

Fu G, Fu X, Liu A. Petroleum systems pool-formation and oil and gas distribution in the middle-shallow strata of Northern Songliao 
Basin. J Southwest Pet Inst. 2001;23(6):1-5. https://doi. org/10.3863/j.issn.1000-2634.2001.05.01.

Gao R, Cai X. Formation conditions and distribution of the oil and gas fields in the Songliao Basin. Beijing: Petroleum Industry Press; 1997. (in Chinese).

Hou Q, Feng Z, Feng Z. Terrestrial petroleum geology of Songliao Basin. Beijing: Petroleum Industry Press; 2009. (in Chinese).

$\mathrm{Hu}$ Y. Geochemical characteristics of crude oils and oil source correlation from Gasikule oilfield of Qaidam Basin. Thesis for the Master Degree in Yangtze University. 2012. (in Chinese)

Kang D, Lv Y, Fu G, Wang L. Research of reservoir characteristics of Saertu reservoir in Western Slope region of North part of Songliao Basin. Natural Gas Geoscience. 2005;16(5):593-8 (in Chinese).

Li D, Li R, Zhu Z, Wu X, Cheng J, Liu F, Zhao B. Origin of organic matter and paleo-sedimentary environment reconstruction of the triassic oil shale in Tongchuan City Southern Ordos Basin (China). Fue. 2017;208(15):223-35. https://doi.org/10.1016/j. fuel.2017.07.008.

Li J. Fouth assessment for oil and gas resource. Beijing: Petroleum Industry Press; 2019. (in Chinese).

Mackenzie AS. Applications of biological markers in petroleum geochemistry. Adv Pet Geochem. 1984;1:115-214. https://doi. org/10.1016/B978-0-12-032001-1.50008-0.

Magoon LB, Dow WG. The petroleum system from source to trap. AAPG Memoir. 1991. https://www.osti.govbiblio/7079288.

Mashhadi ZS, Rabbani AR. Organic geochemistry of crude oils and Cretaceous source rocks in the Iranian sector of the Persian Gulf: an oil-oil and oil-source rock correlation study. Int J Coal Geol. 2015;146:118-44. https://doi.org/10.1016/j.coal.2015.05.003.

Meng Q, Zhao B, Liang J, Sun G, Peng J, Bao L, Li Y, Huo L, Ma Y. Hydrocarbon accumulation factors of the slope area outside of source area: a case study of West Slope area in Northern Songliao Basin. Acta Geol Sin . 2014;88(3):434-46 (in Chinese).

Peters KE, Moldowan JM. The Biomarker Guide Prentice. Hall Englewood Cliffs, NJ. 1993;363.

Peters KE, Walters CC, Moldowan JM. The Biomarker Guide Biomarkers and Isotopes in Petroleum Exploration and Earth History, vol 2. Cambridge University Press Cambridge. 2005;66-567.

Rowland SJ. Production of acyclic isoprenoid hydrocarbons by laboratory maturation of methanogenic bacteria. Org Geochem. 1990;15(1):9-16. https://doi.org/10.1016/0146-6380(90)90181-X.

Rontani JF, Bonin P, Vaultier F, Guasco S, Volkman J. Anaerobic bacterial degradation of pristenes and phytenes in marine sediments does not lead to pristane and phytane during early diagenesis. Org Geochem. 2013;58:43-55. https://doi.org/10.1016/j.orggeochem .2013.02.001.

Schoell M. The hydrogen and carbon isotopic composition of methane from natural gases of various origins. Geochim Cosmochim Acta. 1980;44(5):649-61. https://doi.org/10.1016/0016-7037(80)90155 $-6$.

Schouten S, Hopmans E, Sinninghe-Damste J. The organic geochemistry of glycerol dialkyl glycerol tetraether lipids: A review. Org Geochem. 2013;54:19-61. https://doi.org/10.1016/j.orggeochem .2012.09.006.

Ten Haven HL, De Leeuw JW, Rullkötter J, Damsté JSS. Restricted utility of the pristane/phytane ratio as a palaeoenvironmental indicator. Nature. 1987;330(6149):641-3. https://doi. org/10.1038/330641a0.

Tissot BP. Recent advances in petroleum geochemistry applied to hydrocarbon exploration. AAPG Bull. 1984;68(5):545-63. https ://doi.org/10.1306/ad461336-16f7-11d7-8645000102c1865d.

Waples DW, Machihara T. Application of sterane and tritepane biomarkers in petroleum exploration. Bull Can Pet Geol. 1990;3:35780. https://doi.org/10.2118/19824-PA.

Wen H. Oil and gas migration law research of the Western Slope in the Northern Songliao Basin. Thesis for the Master Degree in Northeast Petroleum University. 2012. (in Chinese)

Zhang L, Bai G, Zhao X, Zhou L, Zhou S, Jiang W, Wang Z. Oil-source correlation in the slope of the Qikou Depression in the Bohai Bay Basin with discriminant analysis. Mar Pet Geol. 2019;109:64157. https://doi.org/10.1016/j.marpetgeo.2019.06.055.

Zhou Q, Lv Y, Fu G, Zhou Q, Jiang L. The pool-forming pattern and main control factors in West Slope of the North of Songliao Basin. Natrual Gas Geoscience. 2006;17(6):765-9. https://doi. org/10.3969/j.issn.1672-1926.2006.06.005.

Zhu X, Zeng H, Li S, Dong Y, Zhu S, Zhao D, Huang W. Sedimentary characteristics and seismic geomorphologic responses of a shallow-water delta in the Qingshankou formation from the Songliao Basin. China Mar Pet Geol. 2016;79:131-48. https:// doi.org/10.1016/j.marpetgeo.2016.09.018.

Zou C, Wang Z, Xu G, Wu X, Sun X, Wang J. Characteristics and genesis of the Western Slope thick oils in Songliao Basin. Acta Sedimentol Sin. 2004;22(4):700-6. https://doi.org/10.1007/BF028 73097. 